\title{
OS CONCURSOS DE BELEZA NA COMUNIDADE NIPO-BRASILEIRA E A IMAGEM DA MULHER NIKKEI ${ }^{1}$
}

\author{
Koichi Mori* \\ Barbara Inagaki**
}

Resumo: O presente trabalho tem como objetivo analisar a transformação da imagem da mulher descendente de japoneses no Brasil no período pós-Segunda Guerra Mundial através dos concursos de beleza promovidos nas comunidades nikkeis, dando especial atenção aos concursos "Miss Colônia" e "Miss Nikkei Internacional", promovidos pelo Jornal Paulista. Para tanto, além da exposição da visão panorâmica da história da imigração japonesa ao Brasil e do desenvolvimento da colônia nikkei, será traçado um paralelo entre o desenvolvimento dos concursos de beleza e a situação socioeconômica da sociedade brasileira.

Palavras-chave: mulher nikkei, concurso miss, história da imigração japonesa no Brasil, identidade feminina, imagem da mulher, comunidade nipo-brasileira.

Summary: The objective of the present work is to analyze the transformation of the Japanese descendent woman's image in Brazil after the Second World War, through the promoted competitions of beauty in the Nikkei Communities, giving special attention to the competitions "Miss Colonia" and "Miss Nikkei International", promoted by the newspaper Jornal Paulista. Therefore, beyond the expositions of the panoramic vision of the history of Japanese Immigration to Brazil and the development of the Nikkei Community a parallel will be traced between the development of the competitions of beauty and the social and economic situation of the Brazilian society.

Keywords: nikkei woman, competition of beauty, history of Japanese immigration to Brazil, feminine identity, woman's image, Japanese - Brazilian community.

\footnotetext{
1. Este trabalho foi realizado com o apoio da Fundação Kunito Miyasaka.

* Professor doutor na Área de Língua e Literatura Japonesa do Departamento de Letras Orientais da FFLCH.

** Aluna de graduação do Curso de Letras Japonês/ Português da FFLCH, bolsista PRP/IC.
} 


\section{Introdução:}

Perto de se completar cem anos da imigração japonesa para o Brasil, muitos estudos foram desenvolvidos acerca da formação da colônia nikkei, de sua estrutura socioeconômica, assim como muitos estudiosos abordaram de forma ampla a questão da língua falada pelos imigrantes e seus descendentes, a religião e outros inúmeros temas.

Entretanto, em meio a essa gama de pesquisas, é possível notar que pouco se tem discutido uma das questões fundamentais da história da sociedade japonesa no Brasil: a mulher nikkei, sua assimilação e transformação.

Assim, o presente artigo tentará resgatar parte da história da mulher nikkei dentro da colônia japonesa e da sociedade brasileira no período pós-Segunda Guerra Mundial através dos concursos de beleza promovidos pelas comunidades japonesas, dando especial enfoque aos concursos realizados pelo Jornal Paulista - "Miss Colônia" e "Miss Nikkei Internacional" - além dos concursos regionais, com o objetivo de traçar uma análise da transformação e assimilação da mulher nikkei dentro da sociedade brasileira e a mudança gradativa de sua imagem.

Tais concursos revelam não somente a transformação da estética e da beleza da mulher japonesa, muitas vezes estereotipada nas últimas cinco décadas, mas também a movimentação da própria colônia japonesa, o seu desenvolvimento e principalmente a sua inserção na sociedade brasileira através de uma intensa interação econômica e social.

Os concursos "Miss Colônia" e "Miss Nikkei Internacional" realizados pelo Jornal Paulista durante mais de vinte anos foram um espaço de integração entre as candidatas de diversas colônias - não somente do Brasil, mas do mundo todo muitas vezes resgatando a identidade japonesa que havia se perdido ao longo das gerações

Através de um breve panorama histórico da imigração japonesa para o Brasil, de entrevistas com os organizadores dos concursos, com as candidatas e com o apoio histórico do desenvolvimento da colônia japonesa e diversas matérias publicadas no Jornal Paulista no período de 1950 a 1994, o presente artigo tentará explorar mais a fundo a questão da mulher nikkei no Brasil, especialmente em São Paulo, estabelecendo, ao mesmo tempo, uma ponte com a expansão gradual da colônia japonesa e com a situação econômica, política e social brasileira. Além disso, será exposta uma visão geral da situação dos atuais concursos de beleza realizados na colônia para que se possa apresentar um panorama amplo sobre a mulher nikkei e a mudança de sua imagem. 


\section{Breve introdução à história da imigração japonesa para o Brasil e os primórdios dos concursos de beleza na colônia japonesa}

\subsection{Uma pequena história da imigração japonesa para o Brasil:}

A imigração japonesa oficial para o Brasil teve seu início com a chegada do navio Kasato-Maru no porto de Santos no dia 18 de junho de 1908. Carregado de 781 trabalhadores temporários contratados pela Companhia Imperial de Colonização Ltda., eles iriam suprir principalmente a mão-de-obra nas fazendas de café do Estado de São Paulo, que "havia entrado no período de recuperação [econômica] da crise cafeeira"2 que atingia o Estado desde 1896. Dentre os 781 imigrantes, apenas 186 eram mulheres, pois a mão-de-obra produtiva era um dos requisitos importantes para o trabalho no campo. Entretanto, elas compartilharam da vida árdua nas lavouras ao lado dos homens e desempenharam afazeres domésticos, sofrendo com a adaptação ao novo ambiente e lutando para alcançar a estabilidade econômica que os havia impulsionado a se lançar numa aventurosa viagem.

Na condição de trabalhadores de curto prazo (decassegui), muitos dos imigrantes "previam sua permanência no Brasil entre 4 a 5 anos, no máximo 10 anos, para, depois de poupar alguns bens, retornarem imediatamente ao Japão, fazendo 'um retorno glorioso"'3. Dentro dessas condições, como lavradores, é que os primeiros imigrantes japoneses foram encaminhados para as diversas fazendas cafeeiras como a Fazenda Floresta, em Itu, a Fazenda Canaã e Dumont, na Linha Mojiana, a Fazenda Guatapará e São Martinho, na Linha Paulista, e a Fazenda Sobrado, na Linha Sorocabana. ${ }^{4}$

Entretanto, sem o objetivo de fixação no Brasil, o imigrante se deslocava freqüentemente nas áreas agrícolas em busca de melhores salários, sendo submetido a péssimas condições de trabalho, de moradia e de alimentação. Assim, "com o passar dos anos [...] os imigrantes japoneses verificaram a impossibilidade de reunir o pecúlio desejado através do trabalho assalariado em um curto período de permanência." Reconhecendo, dessa forma, a dificuldade de retorno imediato ao

2. ZENPATI, Ando \& WAKISAKA, Katsunori - "Sinopse histórica da imigração japonesa no Brasil", IN: Consulado Geral do Japão, “O japonês em São Paulo e no Brasil”, São Paulo, 1971, p.22

3. MORI, Koichi "Burajiru no Nihonjin to Nihongo (Kyôiku): Os japoneses e a Língua Japonesa (ensino)"

(In) Revista Mensal Kokubungaku Kaishaku to kanshô (Literatura Nacional- Interpretação e Leitura) 2006.7 Vol.71. No.7 p.7

4. HANDA, Tomoo - "Geografia das seis fazendas (Lavouras em que foram distribuídos os imigrantes)", IN: O imigrante japonês, história de sua vida no Brasil, T.A Queiroz, Editor/Centro de Estudos Nipo-Brasileiros, São Paulo, 1987, pp.19 21.

5. ZENPATI, Ando \& WAKISAKA, Katsunori, op. cit. p.31 
Japão, a partir da década de 20, "a estratégia de imigração do decassegui de curto prazo mudou para a estratégia de imigração de médio e longo prazo"6.

Os japoneses, mesmo com essa nova estratégia de maior permanência no Brasil, ainda mantinham o ideal de retorno à pátria, estendendo a estada com o intuito de poupar maior quantidade de bens. Entretanto, nessa fase se nota uma organização social e econômica mais concreta no sentido de passarem da condição de arrendatários para a de pequenos proprietários ${ }^{7}$, adquirindo lotes de terra para "[...] fundar núcleos coloniais semi-permanentes exclusivamente de japoneses"8. Os terrenos poderiam ser áreas de mata virgem cedidas pelos próprios donos de fazenda ou poderiam ser comprados com algum tipo de poupança, quando houvesse.

Nessas terras, os japoneses passaram a cultivar seu próprio café, alcançando altos índices de produção, que sofreu forte impacto com a crise cafeeira em 1929, resultado da quebra da bolsa de valores de Nova Iorque no mês de outubro do mesmo ano.

Entretanto, apesar da crise cafeeira, o trabalho árduo nas lavouras de café havia "contribuído para que o lavrador adquirisse terras, [...] e a posse da terra representava a construção de uma base econômica mais estável"9. Dessa forma, todos esses fatos contribuíram para a intensa dinamização da produção agrícola dos japoneses, que já vinha se desencadeando principalmente desde a década de 20 , com o desenvolvimento de técnicas de cultivo de produtos como o algodão, arroz e batata, dentre outros. Enquanto a produção de café, que em 1912 representava $92,6 \%$ da atividade dos imigrantes, caiu para $32,1 \%$ no final da década de $30^{10}$.

Esse desenvolvimento da agricultura foi favorecido ainda por diversas condições na década de 20: nesse período, "o auxílio às despesas de viagem da imigração japonesa para o Brasil foi transferido do governo de São Paulo para o governo japonês. Com a falta de mão-de-obra nas fazendas de café de São Paulo, a condição ruim da economia japonesa e a medida de proibição da imigração por parte do governo italiano, fez o número de imigrantes japoneses crescer rapidamente"11.

\footnotetext{
6. MORI, Koichi, op. cit. p.10

7. SAITO, Hiroshi. A presença japonesa no Brasil, São Paulo, Edusp, 1980, p.85

8. ZENPATI, Ando \& WAKISAKA, Katsunori, op. cit. p.31

9. Comissão de Elaboração da História dos 80 anos de Imigração Japonesa no Brasil - Uma epopéia moderna: 80 anos de imigração japonesa no Brasil, São Paulo, HUCITEC: Sociedade Brasileira de Cultura Japonesa, 1992, p.121

10. Idem, p.122

11. MORI, Koichi, op. cit. p. 15
} 
Assim, o aumento da população japonesa e o início da independência agrícola através da aquisição de terras permitiram que a colônia alcançasse seu período de maior prosperidade na década de 30 .

Acompanhando o processo de formação de núcleos coloniais, surgiram diversas associações japonesas que tinham como funções "o controle dos assuntos de saúde e higiene dos colonos, a manutenção e conservação de estradas e pontes, o estudo do problema educacional dos filhos e sua orientação, ampliação da escola primária e construção de novos prédios e instalações necessárias às atividades produtivas, inclusive meios de transporte", entre outras ${ }^{12}$. Ou seja, elas tinham a função de manutenção e auxílio das comunidades recém-abertas. Mais tarde, principalmente no período pós-guerra, essas associações, além das funções sociais, passam a incorporar funções culturais, como ocorre com as associações juvenis, que passam a promover competições esportivas e bailes, entre outros eventos, como os concursos de beleza, a serem comentados posteriormente.

Diferentemente do período inicial de imigração de curto prazo, os imigrantes de médio e longo prazo tiveram grande preocupação em relação à educação de seus filhos, já que novas gerações estavam nascendo no Brasil. Dessa forma, houve uma grande movimentação nas comunidades rurais a fim de instruir seus filhos, organizando-se escolas e associações administrativas.

A imprensa também sofre grande salto nessa época: os jornais japoneses editados no Brasil, que haviam iniciado suas atividades na década de 1910, acompanhando o crescimento e a estabilização da colônia, passam a ser publicados diariamente no final da década de $30^{13}$.

No entanto, é também no final dos anos 30 que a comunidade japonesa sofre as conseqüências da política brasileira: com a instauração do Estado Novo por Getúlio Vargas em 1937, diversas leis restritivas nacionalizantes foram aplicadas rigorosamente entre 1938 e 1939, visando "a uniformização, a padronização cultural e a eliminação de quaisquer formas de organização autônoma da sociedade, que não fossem na forma de corporações rigorosamente perfiladas com o Estado"14. Além disso, o rompimento diplomático entre o Brasil e os países do Eixo durante a Segunda Guerra Mundial ajudou a fortalecer a repressão contra japoneses.

Dessa forma, a comunidade japonesa, que já havia alcançado certo grau de organização estrutural, passa a sofrer forte censura por parte do governo brasileiro

12. Comissão de Elaboração da História dos 80 anos de Imigração Japonesa no Brasil, op. cit. p.206

13. MORI, Koichi, op. cit. p.13

14. TONGU, Érica A. S. Resistência de Seda: um estudo preliminar sobre a nacionalização dos imigrantes japoneses e a educação no Brasil, Dissertação de mestrado, Universidade de São Paulo, 2002, p.106 
com vistas à assimilação dos japoneses na sociedade brasileira. Tais medidas afetam diretamente a comunidade em diversos aspectos, dentre eles os mais destacados são:

- A educação: desde 1933 diversas leis restritivas haviam sido aplicadas, mas é em 1938 que ocorre o fechamento de todas as escolas de língua estrangeira.

- A mídia: os jornais que haviam iniciado suas atividades já na década de 1910 sofreram grandes restrições no final da década de 30, quando "o governo federal brasileiro anunciou oficialmente o controle sobre os jornais e revistas publicadas em língua estrangeira, obrigando-os a anexar a tradução das principais matérias e o editorial em língua portuguesa"15, até que, em 1941, a publicação de tais jornais foi totalmente proibida.

Dentro dessas condições eclode a Segunda Guerra Mundial, e, com a derrota do Japão, os imigrantes japoneses não mais tinham a esperança de retornar à sua pátria, partindo para a terceira estratégia de vida: a permanência definitiva no Brasil.

\subsection{Os primórdios dos concursos de beleza na colônia japonesa:}

Com a decisão de permanência definitiva no Brasil após a Segunda Guerra, os japoneses que vieram na condição de imigrantes passam a carregar novos objetivos: a inserção na sociedade brasileira e a busca pela ascensão social. E esse desejo pode ser apontado como um dos fatores que deu início aos primeiros concursos de beleza realizados nas colônias japonesas rurais.

A estabilidade que haviam alcançado no setor agrícola com a possibilidade de aquisição de terras e a diversificação de produtos fez com que os japoneses, além de cultivar e vender, partissem para uma terceira etapa: a promoção e a divulgação de seus produtos, tanto dentro das próprias colônias como para os governos locais brasileiros.

Dessa forma, no período pós-guerra, as colônias japonesas passaram a promover seus produtos através da realização de festas locais anuais que reuniam diversos produtores para a exposição dos produtos de mais destaque em cada região. Assim, Itaquera promovia sua "Festa do Pêssego", Mogi das Cruzes, a "Festa do Caqui", Bastos, a "Festa do Ovo", Indaiatuba realizava a "Festa do Tomate", Ferraz de Vasconcelos destacou-se com a "Festa da Uva", Santo André promoveu a "Festa da Verdura", Bragança Paulista promoveu a "Festa da Batata", etc ${ }^{16}$. Nas festas, além da exposição dos produtos, havia outras atrações como apresentação de dança japonesa, exposição de ikebana, de fotografia e apresentação de bandas. E

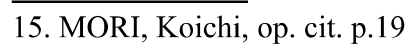

16. A região de cultivo de alguns produtos muda conforme a época e assim a festa também é transferida. 
justamente uma das atrações de grande destaque dentro de tais festas era a escolha das "rainhas": três a cinco moças descendentes de japoneses e, algumas vezes, brasileiras eram indicadas por associações para concorrer aos títulos de "Rainha do Ovo", "Rainha do Caqui", "Rainha do Tomate", "Rainha da Uva", "Rainha do Pêssego", "Miss Laranja", dentre outros, através da venda de votos. A candidata que recebesse maior número de votos era coroada "rainha" e as demais recebiam o título de "princesa".

O primeiro concurso de beleza promovido na colônia japonesa do qual se tem registro foi a eleição da "Rainha do Ovo" em Bastos, datado de 1948, seguindo-se a ele a "Rainha do Pêssego", eleita na "Festa do Pêssego" em Mogi das Cruzes em $19499^{17}$. A partir daí, a eleição de "rainhas" em festas ou feiras agrícolas passou a se popularizar e, em 1961, a votação da "Rainha do Caqui" em Mogi das Cruzes chegou a somar 150 mil votos ${ }^{18}$.

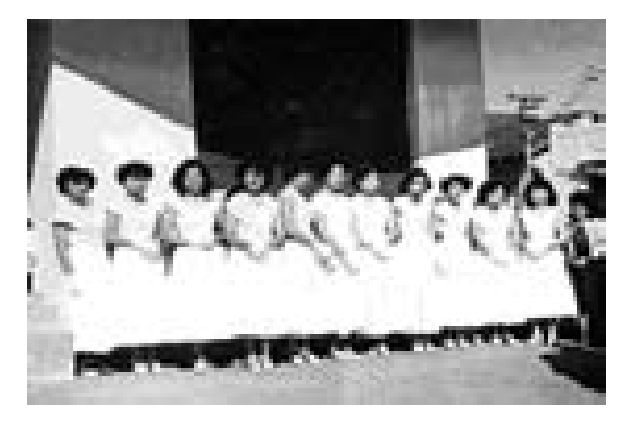

As candidatas a "Rainha do Ovo" na primeira "Festa do Ovo" de Bastos, em 1948 (Fonte: Acervo do Museu da Imigração Japonesa no Brasil)

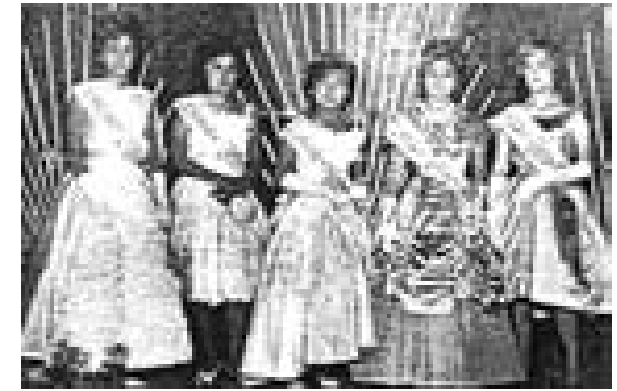

Vencedoras da "Festa do Caqui", 1964 (Fonte: Acervo do Museu da Imigração Japonesa no Brasil)

Entretanto, observa-se que aqui a escolha das "rainhas" e "princesas" não estava vinculada direta ou necessariamente à beleza das candidatas, já que não havia nenhum tipo de regulamentação para a participação ou seleção, o objetivo central era alcançar a maior venda dos votos, sendo a quantia arrecadada muitas vezes destinada ao pagamento das despesas da própria festa.

Esse caráter comercial é enfatizado pela grande participação de políticos brasileiros, prefeitos, governadores e ministros da agricultura, como pode ser observado no pequeno excerto publicado no Anuário do Jornal Paulista de 1964, intitulado "A Nona Festa do Caqui em Mogi”:

17. Não foi possível localizar a data exata do início de cada concurso, então há controvérsia em relação a essas datas.

18. Anuário do Jornal Paulista, ano 1962, p.8 
“A nona 'Festa do Caqui' realizada pelas associações Agrícola e Cultural de Mogi nos dias 6 e 7 no Clube União, foi inaugurada com a presença do governador de São Paulo, Ademar, com o Ministro da Agricultura. Thompson e com o presidente da Assembléia, Ciro. ${ }^{\prime 19}$

Assim, a organização de tais festas reflete uma abertura por parte da colônia japonesa na tentativa de maior interação com a economia nacional, entrando na competição do mercado brasileiro por meio da apresentação maciça de seus produtos. E foi através desses festivais e da eleição das "rainhas" e "princesas" que a mulher nikkei também começou a ser "apresentada" para a sociedade brasileira.

\section{Os concursos de beleza realizados pelo Jornal Paulista - Miss Colônia e Miss Nikkei Internacional}

Os concursos de beleza, que até então aconteciam durante os festivais, ganham um espaço próprio e exclusivo quando o Jornal Paulista decide realizar o seu primeiro concurso de beleza, o "Miss Colônia", na década de 50. Acompanhado por algumas dificuldades, o concurso é promovido somente por dois anos, retomando a sua realização na década de 70, num contexto muito distinto dos anos 50 .

Assim, para melhor abordagem do tema, os concursos realizados pelo Jornal Paulista serão divididos em duas fases:

1. Primeira Fase: a realização nos anos 50

2. Segunda Fase: dos anos 70 aos anos 90

\subsection{A primeira fase dos concursos - Anos 50 -}

Com o fim da Segunda Guerra e da enérgica censura por parte do governo brasileiro aos japoneses, o desejo de estabelecimento na sociedade brasileira e a preocupação com a educação de seus filhos e sua ascensão social impulsionaram o início do deslocamento da população rural japonesa para as cidades, principalmente para São Paulo. As famílias que já haviam acumulado capital com o trabalho agrícola agora possuem novos objetivos: "oferecer um patrimônio e 'uma vida melhor' para os filhos" ${ }^{20}$. Entretanto, apesar dessa mudança do campo para a cidade na década de 50 , apenas $44,9 \%$ da população japonesa era considerada como urbana ${ }^{21}$. A maioria dos japoneses ainda se apresentava concentrada no meio rural no final da década de 50 .

19. Anuário do Jornal Paulista, ano 1964, p. 23, traduzido do japonês.

20. CARDOSO, Ruth C. L. - Estrutura Familiar e mobilidade social, estudo dos japoneses no Estado de São Paulo, São Paulo, Kaleidos -Primus Consultoria e 112 Comunicação integrada S/C Ltda, 1998, p.70

21. SUZUKI, Teiichi - Mobilidade geográfica de imigrantes japoneses, IN: Consulado Geral do Japão, $O$ japonês em São Paulo e no Brasil, São Paulo, 1971, p. 97 
Assim, mesmo com o surgimento de novas gerações, as mulheres japonesas ainda viviam no meio rural, muitas vezes ajudando no trabalho do campo e, em razão das poucas opções de vida que lhes eram oferecidas, seja por motivos econômicos seja por outras questões, como adaptação, ainda não freqüentavam universidades, não formavam carreira.

A colônia japonesa, tanto do interior como das capitais, retomou o estabelecimento de sua estrutura sociocultural, a começar pela volta da edição dos jornais em língua japonesa, sendo criado em 1947 o Jornal Paulista. Seguindo essa retomada das atividades da comunidade, inicia-se um forte processo de criação de associações juvenis que incluem em seu calendário atividades esportivas (passando a realizar competições entre clubes), culturais e sociais, visando à integração dos jovens descendentes de japoneses.

Com a fundação do Jornal Paulista, essa integração da comunidade nikkei ganha um novo rumo, representando também a integração das mulheres nikkeis. $\mathrm{O}$ Jornal, na ocasião em que estava comemorando dez anos de fundação, dá seu passo inicial com a realização do primeiro "Miss Colônia" em 1957 para escolher a mais bela nikkei da comunidade japonesa ${ }^{22}$.

O concurso surgiu, segundo Paulo Ogawa (ex-diretor do Jornal Paulista) e Getúlio Kamiji (ex-diretor do programa "Japan Pop Show"), com o objetivo de integrar não somente as mulheres descendentes de japoneses, mas a comunidade nikkei, já que o concurso, nessa primeira fase, recebia candidatas de diversos estados brasileiros que tivessem uma colônia japonesa.

O concurso funcionava da seguinte maneira: o Jornal Paulista comunicava a intenção da realização do concurso "Miss Colônia" através de anúncios no jornal, e, para a aceitação da candidata, era imprescindível que ela fosse indicada por uma associação japonesa. Cada associação promovia uma pré-seleção das moças para escolher apenas uma candidata a ser enviada para São Paulo. Dentro dessas condições é que o Jornal promove o seu primeiro concurso em 1957. Nesse ano, o Jornal recebeu inscrição de candidatas de diversas regiões do Brasil, como Paraná, Mato Grosso e Rio de Janeiro, além das candidatas de todo o Estado de São Paulo. Dentre elas, 12 foram selecionadas para a fase final.

22. Em 1954 houve outro concurso também intitulado "Miss Colônia", realizado na ocasião da comemoração dos 400 anos de São Paulo, sem relação com o Jornal Paulista. 
Após a inscrição devidamente efetivada por cada instituição, as moças enfrentavam uma rigorosa banca examinadora composta por figuras de grande peso na comunidade nipônica, tais como Kunito Miyasaka e Michie Akama ${ }^{23}$, não havendo a participação de jurados brasileiros. As moças eram submetidas a uma análise minuciosa que verificava a proporção física (avaliada em traje de banho somente pelo corpo de jurados feminino em um recinto separado, medindo-se a altura, peso, busto, cintura, quadril e até mesmo o comprimento do rosto ${ }^{24}$ ) e os conhecimentos gerais (avaliados através de entrevistas individuais em que todos os jurados faziam perguntas simples e buscavam saber o grau de instrução de cada candidata), além da postura e da beleza.

Sobre as etapas de seleção do "Miss Colônia 1957" a revista Arigatô $^{25}$ registra:

"O concurso naquela época tinha critérios seletivos muito mais rígidos e diferentes dos atuais. Constava de testes de beleza (fisionomia e formas do corpo), cultura e etiqueta social. Era muito mais uma maratona em que a moça era analisada não só pela sua bela expressão, mas também pelo que poderia apresentar em termos de finesse e conhecimentos gerais. (...) É curioso notar que, dentro dos padrões de decoro e moral da época, o desfile de 'formas do corpo'se dava em recinto fechado, individualmente e somente para a parte feminina do júri que escolhia a candidata que tivesse as linhas mais perfeitas, dignas de uma Miss Colônia. Posteriormente havia o desfile em traje soirèe, destinado a todo o público, ocasião em que eram julgadas pelo corpo de jurados especialmente escolhidos."

Conseguindo ultrapassar todas as etapas da seleção, deixando para trás onze concorrentes, Geny Toshie Fukuda (agora Sra. Sanematsu) se consagrou a primeira "Miss Colônia" no dia 19 de janeiro de 1957. Representando o Esporte Clube Linense, Geny conquistou os olhares apurados dos jurados e se tornou a representante pioneira da beleza japonesa no Brasil. Além da eleição da "Miss Colônia", Nakano Shôko e Ikeda Satoko foram eleitas "Primeira Princesa" e "Segunda Princesa", respectivamente. Após o anúncio dos resultados, se realizou uma cerimônia para coroação e entrega das faixas.

23. Kunito Miyasaka foi fundador do Banco América do Sul, e Michie Akama fundou uma das primeiras escolas de corte e costura, a Escola de Corte e Costura Akama.

24. Anuário do Jornal Paulista, 1972.

25. Revista Arigatô, ano 1, nº 5, abr. 1977, p.4. 


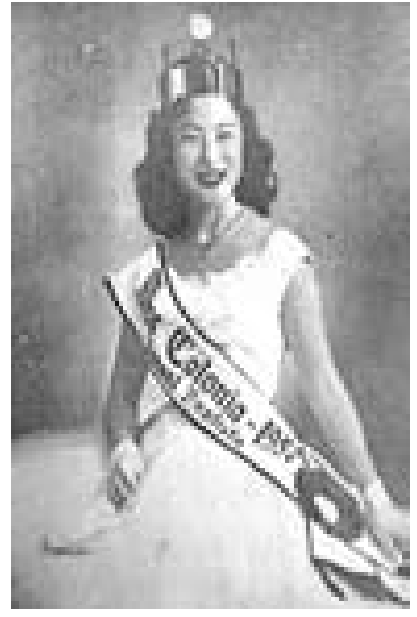

Geny Sanematsu, vencedora do "Miss Colônia 1957"

(Fonte: Museu da Imigração Japonesa no Brasil)

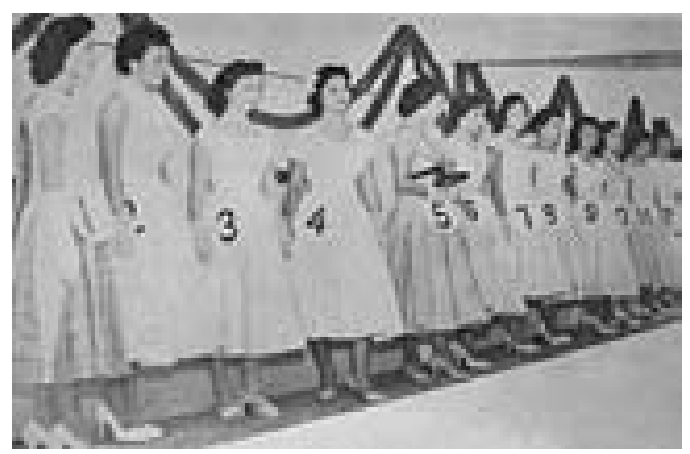

As candidatas ao "Miss Colônia 1957" (Fonte: Museu da Imigração Japonesa no Brasil)

O concurso, apesar da grande adesão na época, foi um evento polêmico na comunidade japonesa, pois as mulheres, que até então encontravam-se ligadas aos afazeres domésticos e ao trabalho nas lavouras das colônias, estavam caminhando em direção oposta à imagem da "mulher japonesa ideal": “(...) a cultura oriental considera como ideal o comportamento recatado. (...) A quietude é, de certa forma, o sinônimo de belo"26. Dessa forma, "havia muita dificuldade para convencer as moças da época a participarem de um concurso de beleza que exigia que (...) mostrassem suas formas, o que ia contra a moral vigente na época. Na maioria das vezes, o preconceito de que 'moça direita não deve participar de concurso de pernas de fora' prevalecia, criando grandes empecilhos, principalmente dentro da colônia japonesa, tradicionalmente rígida em termos de recato" 27 .

Essa rigidez no comportamento da mulher japonesa se deve em grande parte à educação recebida na família, com forte influência materna. Por outro lado, o fato de pertencer a uma comunidade fechada, com predominância rural, isolava as jovens da sociedade brasileira e, de certa forma, fazia com que seu ideal de vida fosse como o de suas mães, casar e formar uma família feliz, alcançar estabilidade, não uma ascensão profissional para se tornarem independentes. Isso evidencia uma divisão clara dos papéis dentro da família:

26. OGAWA, Felícia Megumi. Problemas de identidade sócio-cultural no Brasil. IN: Cadernos, n¹6, $1^{`}$ série, nov. de 1981, Centro de Estudos Rurais e Urbanos, São Paulo, p.29.

27. Revista Arigatô, op. cit., p.4 
"Na familia-modelo dessa época, os homens tinham autoridade e poder sobre as mulheres e eram responsáveis pelo sustento da esposa e dos filhos. A mulher ideal era definida a partir dos papéis femininos tradicionais - ocupações domésticas e o cuidado dos filhos e do marido - e das características próprias da feminilidade, como instinto materno, pureza, resignação e doçura. " 28

Assim, Geny Sanematsu registrou na sua entrevista à revista Arigatô:

"Naquela época, não era costume a mulher estudar. E, se quisesse, teria que sair para a cidade grande, e isso era coisa para os rapazes". ${ }^{29}$

Além desse modelo "ideal" de mulher que vigorava na época, outro dado caracterizou o concurso de forma marcante na década de 50. Apesar de não haver um registro sobre a geração exata das candidatas, é possível notar através da análise das fotos que praticamente todas eram descendentes "puras" de japoneses, não havendo candidatas mestiças. Como causa desse quadro, duas hipóteses socioculturais podem ser levantadas:

- O primeiro fator que pode ser apontado como causa da presença exclusiva de descendentes "puras" é o quadro dos casamentos interétnicos (casamento entre descendentes de japoneses e não-descendentes, no caso). Segundo o Censo realizado pela Comissão de Recenseamento da Colônia Japonesa, no período de 1953 a 1958, a porcentagem de casamentos interétnicos entre imigrantes era de apenas $4,8 \%$, assim como apenas $4,5 \%$ dos casamentos entre os descendentes nascidos no Brasil eram interétnicos ${ }^{30}$. Ou seja, a grande maioria dos descendentes de japoneses ainda era "pura", dado que sofre significativa alteração nas seguintes décadas.

- Outra hipótese sobre a ausência de participação de mestiças é o forte preconceito em relação à miscigenação racial que predominava na época, um tipo de segregação que talvez tenha sido a arma das minorias étnicas que desejavam perpetuar os valores culturais de sua própria etnia ${ }^{31}$. Kiyotani Masuji, em "O casamento interétnico do filho e o neto mestiço", analisa diversos tankas ${ }^{32}$ escritos por imigrantes, nos quais estes exprimem seus sentimentos sobre o casamento de seus filhos e filhas com pessoas não-descendentes e sua reação diante dos netos mestiços. Para os imigrantes, o nascimento do neto significava a continuidade na

28. BASSANEZI, Carla. "Mulheres nos Anos Dourados", IN: História das mulheres no Brasil, Mary del Priore (org), São Paulo, ed. Contexto, 2001, pp.608 609.

29. Revista Arigatô, op. cit., p.4

30. Comissão de Recenseamento da Colônia Japonesa, 1964, The Japanese Immigrants in Brazil, Tokyo, University of Tokyo Press, p.356.

31. OGAWA, Felícia Megumi, op. cit., p. 31

32. Um tipo de poesia japonesa constituído por um conjunto de 31 sílabas. 
transmissão dos valores da família japonesa, da cultura japonesa, e "o filho unir os laços com um ‘estrangeiro' não era apenas uma traição em relação aos pais, mas era algo vergonhoso na comunidade japonesa, era um ato que deveria até mesmo ser desprezado"33. Esse sentimento de rejeição foi expresso em algumas poesias, em que alguns imigrantes consideram o casamento interétnico até mesmo como "uma das tragédias da história da imigração japonesa".

E, sem dúvida, a questão da miscigenação recaiu com maior intensidade sobre as mulheres: "a miscigenação, sempre acompanhada de seu contrário - a 'pureza racial', afunila-se, concentra-se e se expressa em termos estéticos na figura do corpo feminino. É a mulher, mais do que o homem, que vem dando maior densidade aos símbolos estéticos ligados ao cromatismo da pluralidade racial (...) e que traça a dialética entre "raça pura' e 'raça mestiça"'34.

Assim, nos anos 50, a mulher mestiça era vista com olhares negativos, e os concursos "Miss Colônia" realizados nesse período acabaram refletindo esse "ideal de mulher japonesa", prevalecendo a presença de mulheres descendentes "puras".

De certa forma, pode-se dizer que foi um conflito entre duas sociedades: a sociedade homogênea de imigrantes japoneses e a sociedade heterogênea brasileira. Os japoneses "acumularam comuns e idênticas experiências na condição de imigrantes, o que serviu para fortalecer seu sentimento de homogeneidade, (...) tornavam-se etnocentristas e exclusivistas, fechando-se dentro da própria comunidade" $" 35$. Entretanto, dentro do contexto social pós-guerra em que se encontrava, a comunidade japonesa caminhava cada vez mais para uma abertura maior, intensificando o contato com a sociedade brasileira e com os brasileiros, tornando-se inevitável a união de seus membros com parceiros não-descendentes.

Dessa forma, é possível notar a rigidez em relação à mulher que ainda prevalecia na comunidade nikkei brasileira na década de 50. Assim, por essas questões é que o "Miss Colônia" promovido pelo Jornal Paulista acaba sendo interrompido após o segundo ano de realização, em 1958.

Nesse ano, vinte candidatas foram indicadas, porém, através das fotografias enviadas ao Jornal, apenas dez foram selecionadas para participar do segundo "Miss Colônia", realizado no dia 31 de maio no Cine Niterói. Celebrando o cinqüentenário

33. KIYOTANI, Masuji. Ko no ishukon to konketsu no mago In: Burajiru Nikkei Koronia Bungei, São Paulo, Centro de Estudos Nipo-Brasileiros, ed. Toppan Press, 2006, p.68.

34. QUEIROZ, Renato. "Estética e Miscigenação", IN: O corpo do brasileiro - estudos de estética e beleza, São Paulo, ed. SENAC, 1999, p.89.

35. Comissão de Elaboração da História dos 80 anos de Imigração Japonesa no Brasil - Uma epopéia moderna: 80 anos de imigração japonesa no Brasil, São Paulo, HUCITEC: Sociedade Brasileira de Cultura Japonesa, 1992 , p.440. 
da imigração japonesa para o Brasil, o concurso contou com a presença do príncipe Mikasanomiya e sua esposa, o que, segundo matéria publicada no Anuário do Jornal Paulista de 1959, "fez com que os conhecimentos culturais [das candidatas] ganhassem mais peso" no momento da seleção. Entre as dez moças, Fujino Utako foi eleita "Miss Colônia 1958", seguindo-se a ela as "princesas" Itô Miyoko e Hayashi Tereza.

Analisando-se a apresentação das candidatas ${ }^{36}$, publicada no Jornal Paulista de 1957 e 1958, de modo geral, tanto as candidatas ao "Miss Colônia 1957" como as candidatas ao "Miss Colônia 1958" seguiam a educação da "boa moça", freqüentando cursos voltados para a formação feminina, como escolas de corte e costura e de beleza. No ano de 1958, das 15 candidatas, oito freqüentavam esses tipos de escola, que tinham como objetivo principal "aprimorar os conhecimentos gerais através da aprendizagem básica para jovens mulheres tais como arte culinária, artesanato e corte e costura, cultivando um melhor modo de vida para que pudessem contribuir para o progresso da vida das mulheres rurais, bem como, através de atividades recreativas coletivas, se tornar uma pessoa afetuosa e compreensiva com outrem, contribuindo para a sociedade." ${ }^{37}$

Assim, muitas mulheres saíam do campo para a cidade apenas para freqüentar tais escolas femininas. Algumas buscavam algum tipo de especialização em corte e costura, por exemplo, e mais tarde, ao retornarem para o campo, se tornavam professoras, passando seus conhecimentos às mulheres rurais que não tinham a oportunidade de ir para a cidade. Muitas mulheres descendentes também trabalharam em salões de beleza após se formar em "escolas de beleza". O Jornal Paulista do dia 9 de abril de 1958 registrou a declaração de uma das candidatas:

"Agora ela freqüenta a escola de beleza e, com orgulho, diz que, através de um trabalho apropriado para mulheres, quer conquistar um futuro feliz". ${ }^{38}$

É interessante notar aqui que, além de a sociedade japonesa já preestabelecer o papel da "mulher ideal", a própria mulher japonesa busca ser "ideal" dentro dos padrões comportamentais da época, freqüentando aulas de culinária ou corte e costura para se tornar a "dona de casa ideal":

36. No ano do concurso, o Jornal Paulista publicavam fotos das candidatas com uma descrição breve de suas características.

37. Comissão de Organização da Comemoração dos 50 anos de Mogi das Cruzes - Takkon eien ni kagayaku (Espírito pioneiro, brilhará eternamente), p.298 (tradução do japonês).

38. Jornal Paulista, 9 de abril de 1958, traduzido do japonês. 
“(...) As jovens que se formavam nessas escolas eram 'mais cotadas para o casamento' ao voltar às colônias do que aquelas que não as haviam freqüentado; muitas delas também montavam novas escolas de corte e costura no interior. (...) Aliás, as escolas eram carinhosamente chamadas de 'escolas de noivas"',39.

$\mathrm{Na}$ Escola de Corte e Costura Akama, por exemplo, fundada por Michie Akama (uma das principais juradas do "Miss Colônia" da década de 50) em 1932, "as aulas não (...) se restringiam a corte e costura, pois havia também aulas de japonês, trabalhos manuais, etiqueta, tênis etc., enfim, tudo o que era necessário para uma futura dona de casa." 40

Essa imagem "ideal" da mulher na década de 50 predominava na sociedade brasileira também. Com o fim da Segunda Guerra, o desenvolvimento industrial brasileiro e a urbanização, "ampliou-se a possibilidade de acesso à informação, [ao] lazer e [ao] consumo" ${ }^{41}$, sendo uma época em que diversas revistas femininas foram publicadas, ditando o comportamento ideal da "boa moça", "ajudando-a" a cumprir o seu papel dentro da família e dentro da sociedade:

"Ser mãe, esposa e dona de casa era considerado o destino natural das mulheres. Na ideologia dos Anos Dourados, maternidade, casamento e dedicação ao lar faziam parte da essência feminina; sem história, sem possibilidades de contestação.

A vocação prioritária para a maternidade e a vida doméstica seriam marcas de feminilidade, enquanto a iniciativa, a participação no mercado de trabalho, a força e o espirito de aventura definiriam a masculinidade. A mulher que não seguisse seus caminhos, estaria indo contra a natureza, não poderia ser realmente feliz ou fazer com que outras pessoas fossem felizes. Assim, desde criança, a menina deveria ser educada para ser boa mãe e dona de casa exemplar. As prendas domésticas eram consideradas imprescindiveis no currículo de qualquer moça que desejasse se casar. E o casamento, porta de entrada para a realização feminina, era tido como 'o objetivo'de vida de todas as jovens solteiras". ${ }^{2}$

Assim, a mulher descendente de japoneses se encontrava entre a imagem ideal de mulher criada tanto pela comunidade japonesa, como pela sociedade brasileira, tendo as atividades limitadas, seguindo o "curso natural" de vida da mulher. Nesse contexto histórico-social é que surge o concurso "Miss Colônia", desafiando o tradicional recato japonês e apresentando as mulheres descendentes à sociedade, para serem admiradas. Entretanto, para a comunidade japonesa, isso pareceu ser

39. DEMARTINI, Zeila de B. F. Relatos orais de famílias de imigrantes japoneses: elementos para a história da educação brasileira, Educ. Soc. Vol 21, nº 72, Campinas, Aug. 2000, p.12

40. Idem, p. 12

41. BASSANEZI, Carla. op. cit., p.608

42. Idem, p.609. 
um passo muito radical ainda, o que fez com que o concurso realizado pelo Jornal Paulista não tivesse mais continuidade na década de 50.

3.2 A segunda fase dos concursos - dos anos 70 aos anos 90 -

Após um período de pausa, é nos anos 70 que o Jornal Paulista retoma a realização do "Miss Colônia" com um formato muito distinto da primeira fase, não apenas pela força com que surge, mas também pelo contexto social de intensa transformação tanto na sociedade brasileira como na comunidade japonesa.

Para melhor análise, o período correspondente será subdividido em duas fases significantes da história do concurso, como segue abaixo:

\subsubsection{Década de 70 - De nacional a internacional}

\subsubsection{Década de 80 a 90 - De amador a profissional}

\subsubsection{Década de 70 - De nacional a internacional}

Em 24 de novembro de 1972, o Jornal Paulista anunciou:

“' Miss Colônia volta a ser promovido pelo Jornal Paulista.'

Volta o concurso mais conhecido da colônia. Todos os clubes e associações

podem inscrever suas candidatas. Prêmios visam viagem ao exterior."

As inscrições para o primeiro "Miss Colônia" da década de 70 haviam sido abertas e, após um longo período de interrupção, em 1973 o Jornal Paulista retomava a realização do concurso. Com caráter nacional, manteve praticamente o mesmo objetivo da década de 50 - "o congraçamento entre as comunidades nipo-brasileiras, o aperfeiçoamento da cultura e rigidez da juventude brasileira" 43 - e seguiu basicamente o mesmo critério para inscrição: as candidatas deveriam ser indicadas por uma associação de sua cidade, não sendo aceitas inscrições individuais.

É em 1972 também que as regras básicas de participação, as quais se mantêm praticamente as mesmas até o fim do concurso, são rigorosamente definidas:

"As inscrições ao concurso Miss Colônia exigem da candidata as seguintes condições:

a. Ser descendente da colonia japonesa

b. Ter (...) 18 anos completos até a data da realização do concurso

c. Ser solteira

d. Ter reputação e conduta moral ilibada

e. Ser indicada por uma entidade sócio-esportivo-cultural

$\overline{\text { 43. Jornal Paulista, }} 24$ de novembro de 1972 
f. Apresentar no ato de fazer a sua ficha de inscrição, se menor de 21 anos, autorização paterna ou responsável legal, autenticada

g. A direção geral do concurso poderá, a critério exclusivo, recusar inscrições de concorrentes que considera inadequadas (...), podendo usar o mesmo critério na recusa de entidades. "44

Definiu-se também as cinco categorias de premiação (essas categorias não são fixas, e sofrem mudanças ao longo do concurso, a serem comentadas): além da escolha da "Miss Colônia", seriam eleitas quatro "Princesas" e uma "Miss Simpatia", escolhida através de votação entre as próprias candidatas. Entre os diversos prêmios que as escolhidas ganhavam, apenas a "Miss Colônia" era contemplada com uma viagem de ida e volta ao Japão, com acompanhante.

Diferentemente dos anos 50, a banca examinadora passou a ser composta, não apenas por figuras da comunidade nikkei, mas por políticos e empresários brasileiros, que, conforme a regulamentação, deveriam avaliar nas candidatas os seguintes itens principais:

"O julgamento das candidatas será feito tendo em vista os seguintes requisitos:

a. Beleza do rosto

b. Perfeição física

c. Graça

d. Personalidade

e. Desembaraço social"

Essas cinco exigências eram básicas e permanecem até o final do concurso, com uma pequena alteração em 1977. A avaliação do júri seria feita em três etapas: a primeira seria o desfile com "vestido de baile", seguindo-se o desfile de maiô, até a última etapa, em que o júri faria perguntas sobre conhecimentos gerais às candidatas. Essas perguntas, segundo Paulo Ogawa, abrangiam principalmente as "atualidades" da época, como política, por exemplo.

Assim, com esses regulamentos e etapas de seleção, é que se inaugurou a segunda fase do concurso "Miss Colônia" em 18 de maio de 1973. Realizado no auditório da Sociedade Brasileira de Cultura Japonesa em São Paulo, contou com 37 candidatas vindas de todo o Brasil e indicadas por inúmeras associações como o Anhangüera Nikkey Clube, Associação Cultural Esportiva Piratininga, Associação dos Okinawanos no Brasil, Associação Nipo-Brasileira do Mato Grosso do Sul, Associação Cultural de Lins, Associação de Jovens de Marília, Sociedade Agricultura de Taiaçupeba Mogi das Cruzes, Associação Cultural e Esportiva

44. Idem 
Saúde, Ipiranga Shinboku-kai, além de outras entidades localizadas em Presidente Prudente, Registro, Presidente Venceslau, entre outras. É possível notar a expansão do concurso em relação à sua primeira fase. $\mathrm{O}$ intercâmbio entre as associações e as colônias se intensifica, o que é observado já pelo aumento significativo no número de candidatas: enquanto na década de 50 não passavam de 15 , nos anos 70 elas chegam a somar mais de 40.

Ganhando o "Miss Colônia" essa dimensão mais ampla, foi imprescindível o apoio de patrocinadores para tornar possível sua realização. Então, a partir de 73, o concurso passa a contar com diversos patrocinadores como a Hirai Autoveículos, a Colorado RQ (fabricante de televisão em cores), a Varig, que oferecia a passagem de ida e volta ao Japão, a Pearl Center, que premiava a "Miss Colônia" com jóias, o Banco América do Sul, o Osaka Plaza Hotel, Buffet Erico, entre outros ${ }^{45}$. E, ao longo do concurso, outras inúmeras empresas colaboram com algum tipo de patrocínio, oferecendo prêmios e cedendo espaço para a promoção do concurso.

Essa não foi a única transformação que ocorreu em relação aos anos 50 . Enquanto na primeira fase o desfile de maiô era realizado em um recinto separado e exclusivamente para a parte feminina do júri, agora, as candidatas desfilam para toda a banca examinadora, não havendo distinção entre os jurados homens e mulheres. Nos anos 50 prevalecia a sagrada "moral feminina", nos anos 70 a mulher passa a exibir seu corpo, e a tradicional imagem da "menina recatada" é gradativamente quebrada pelas próprias candidatas. O Jornal Paulista publicou o seguinte editorial:

"Nesse concurso, diversos prêmios como a viagem ao Japão são oferecidos para as candidatas eleitas e participantes. Entretanto, grande parte delas não participa do concurso apenas pelos prêmios. (...) Elas querem experimentar subir no palco, se auto-desafiar, querem ser avaliadas como a mais bonita dentre as moças de sua geração, o que é bem típico das moças atuais. Isso não revela mais do que o desejo de mudar a sua vida cotidiana de forma ativa, sendo a participação no concurso um formato concreto para realizá-lo. Nos anos cinqüenta o concurso também foi realizado, mas na época não houve o desfile de maiô. Segundo as candidatas, é porque havia muita resistência por parte dos pais. Agora, pode-se dizer que é a filha quem tem o poder de decidir. Em parte, ainda há pais que 'proíbem'ou as próprias filhas que evitam [esse tipo de exposição], mas isso é natural. "46

Inaugurando dessa forma o concurso da década de 70, Rosa Maria Fukugawa é eleita "Miss Colônia" no ano de 1973, seguida por Celina Arima, a "Primeira Princesa", e Margarete Ide, "Segunda Princesa".

$\overline{\text { 45. Jornal Paulista, }} 23$ de março de 1973

46. Jornal Paulista, 16 de abril de 1974, traduzido do japonês. 


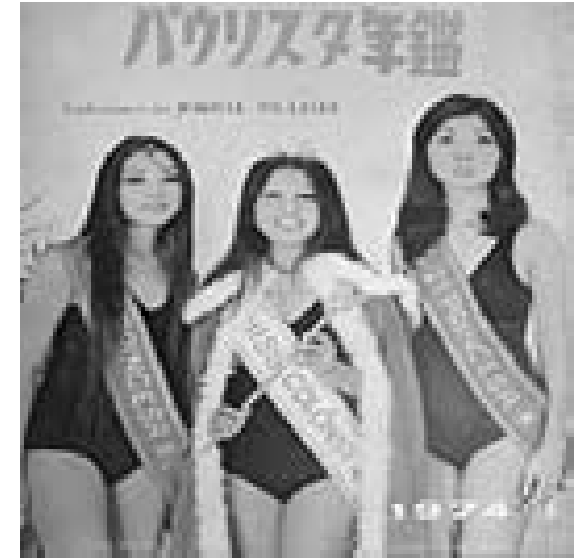

As vencedoras do primeiro "Miss Colônia" realizado em 1973. (Fonte: Museu da Imigração Japonesa no Brasil)

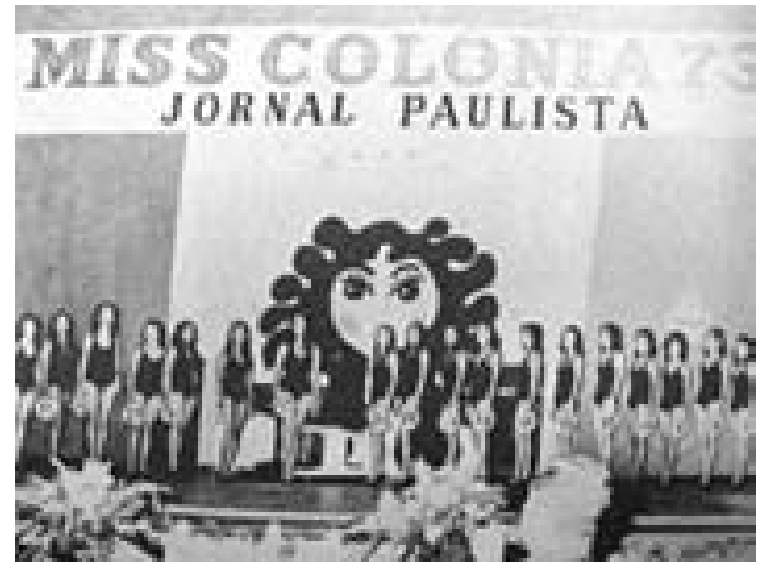

Desfile das candidatas ao "Miss Colônia 1973". (Fonte: Museu da Imigração Japonesa no Brasil)

Esse resultado despertou uma polêmica muito grande entre os organizadores do concurso e o público, polêmica que, na verdade, iria se manter ao longo das demais edições do "Miss Colônia". A primeira classificada desse ano, Rosa Maria Fukugawa, era mestiça, enquanto Celina Arima era descendente "pura" de japoneses. Isso gerou um conflito em diversos níveis do concurso, e Getúlio Kamiji afirma: "Nos primeiros concursos [da década de 50], todas tinham um rosto típico, genuinamente japonês. No segundo concurso [realizado na década de 70] começaram a aparecer as mestiças, tinha mais mistura do que no primeiro concurso. E começaram a falar que o nosso concurso acabaria perdendo a autenticidade da miss japonesa".

A questão da participação da descendente mestiça vem à tona com a eleição de uma mestiça logo na primeira edição do concurso da década de 70. Getúlio Kamiji ainda lembra que muitos questionaram o fato de não ter sido eleita Celina Arima a "Miss Colônia", já que ela, sendo descendente "pura" e representante mais "fiel" da beleza da mulher japonesa, deveria ser mais valorizada. Isso não deixa de ser uma preocupação, não apenas com o caráter do concurso, mas também com a "afirmação de uma identidade grupal específica"47, que pouco a pouco começava a perder o seu modelo tradicional para dar espaço a uma nova imagem da mulher nikkei, a mulher nikkei mestiça.

Talvez pela persistência do conflito, o Jornal Paulista, na edição de 11 de maio de 1976, publica a seguinte matéria:

47. QUEIROZ, Renato - "O corpo, artefato da cultura", IN: O corpo do brasileiro - estudos de estética e beleza, São Paulo. ed. SENAC, 1999, p.21. 
"A propósito de uma dúvida suscitada no interior com relação à participação de mestiças (...) temos a dizer que nada temos contra a participação (...) e o regulamento do concurso não prevê de forma alguma discriminação desse tipo."

Esse aumento no número de mestiças se deve, principalmente, à evolução do quadro de casamentos interétnicos na comunidade japonesa. Enquanto na década de $504,5 \%$ dos casamentos era com não-descendentes, esse número sobe para $45,9 \%$ segundo a pesquisa populacional de $1988^{48}$, e, a cada nova geração que surgia, havia a tendência de maior grau de miscigenação. Pode-se dizer que a década de 70 foi um período de transição da imagem negativa da mulher mestiça para uma imagem positiva, que será fortalecida principalmente a partir da década de 80 .

Além disso, o editorial do Jornal Paulista também registra:

"Quando questionadas sobre o objetivo de vida (...), não há uma que fale que quer formar uma família e se tornar uma dona-de-casa comum. Algumas desejam se graduar em economia, medicina, arte e engenharia, se tornar professora em escolas com bom conceito. Dentre elas, algumas já estão seguindo o caminho para alcançar o seu objetivo",49

Ou seja, os planos de vida da mulher nikkei estavam se alterando, fato que pode ser relacionado a três circunstâncias históricas: o movimento feminista, a situação econômica brasileira e a mudança na estrutura da colônia japonesa.

É a partir da década de 60 que a imagem da mulher passa por uma revolução. Ela começa a buscar seu espaço dentro da sociedade e clama por direitos trabalhistas:

"Os anos 60 inauguram o novo ciclo. (...) O ideal da fada do lar já não tem a unanimidade: na imprensa, multiplicam-se os artigos que evocam a insatisfação da mulher de interior, suas frustrações, a monotonia de sua vida. A acusação contra a mulher sem profissão não vai mais cessar e serão radicalizadas pelas novas correntes feministas". ${ }^{50}$

Com a emergência dos movimentos feministas e a busca por novos direitos, a mulher passa a recusar a "identidade constituída exclusivamente pelas funções de mãe e de esposa" 51 , abandonando a rigidez moral da "boa moça" para se assumir enquanto mulher e conquistar novos objetivos de vida, substituindo as "escolas de noiva" pela universidade, e o casamento pela carreira profissional.

O Brasil, já na década de 50, havia iniciado um processo intenso de reformulação do sistema econômico com a entrada de Juscelino Kubitschek em 1956. A construção

\footnotetext{
48. Relatório de Pesquisa da Comunidade Nikkei, Centro de Estudos Nipo-Brasileiros, 2002, p.87.

49. Jornal Paulista, 16 de abril de 1974, traduzido do japonês.

50. LIPOVETSKY, Gilles. "A mulher no trabalho", IN: A terceira mulher - permanência e revolução do feminino, Maria Lúcia Machado (trad), São Paulo, Companhia das Letras, 2000, p.218

51. Idem, p. 220
} 
de usinas elétricas, o desenvolvimento do transporte e a criação de Brasília foram algumas das significativas transformações que impulsionaram a economia brasileira, fazendo com que, no final dos anos 60 , surgisse o período do "milagre econômico" brasileiro. Com o desenvolvimento da indústria e a urbanização, surgia demanda por mão-de-obra nas cidades, onde as atividades econômicas se concentravam e se diversificavam cada vez mais.

A colônia japonesa, acompanhando esse processo de desenvolvimento, também inicia o movimento de deslocamento do campo para a cidade. Decidida a permanência definitiva no Brasil, o grande objetivo agora era alcançar um status social, e "os pais isseis queriam que os filhos seguissem carreiras profissionais que permitissem sucesso material rápido." ${ }^{52}$

Assim, principalmente na década de 70, os descendentes de japoneses passam a se inserir na sociedade brasileira, em todas as áreas profissionais. É nessa época que eles começam a "aparecer" na política, na mídia, crescendo o número de nikkeis que desejam formar uma carreira, entrar em uma universidade e se tornar um profissional.

Entretanto, para a comunidade japonesa, essa busca pelo objetivo de vida significou também o "abrasileiramento" de seus filhos e netos. A respeito da vencedora do concurso realizado em 1975, Marly Setsuko Matsuura, o jornal japonês Hôchi Shimbun publicou uma matéria com o título "A miss japonesa que não fala japonês", em que a candidata declara: "No Brasil, o pensamento de que só porque é nissei deve saber falar a língua japonesa é ultrapassado" ${ }^{53}$.

Essa mudança na forma de pensar da mulher descendente de japoneses causou um episódio muito curioso no concurso de 1975, divulgado na edição do dia 5 de junho do Jornal Paulista:

“'Esclarecimentos com a Miss Araçatuba' - Na apresentação das candidatas ao público e principalmente ao corpo de jurados, além dos desfiles, elas passam por um 'teste' com várias perguntas do apresentador Nelson Matsuda. A concorrente de Araçatuba, a jovem estudante Cecília Setsuko Maekawa (...) respondeu, dentre outras perguntas, a questão: uma vez casada, quem irá mandar em casa, o marido ou você? Como era uma questão delicada, convencionou-se que ela iria responder afirmativamente, 'sou eu'. Esta brincadeira do animador Nelson Matsuda, do Japan Pop Show, não foi bem interpretada por vários telespectadores, principalmente de Araçatuba. A direção geral do concurso esclarece que

52. Comissão de Elaboração da História dos 80 anos de Imigração Japonesa no Brasil - Uma epopéia moderna: 80 anos de imigração japonesa no Brasil, São Paulo, HUCITEC: Sociedade Brasileira de Cultura Japonesa, 1992, p.435

53. Jornal Paulista, 8 de agosto de 1975, traduzido do japonês. 
a pergunta foi ensaiada com objetivo de causar impacto dentro das concorrentes que se achavam nervosas".

A independência da mulher nikkei ainda causava certo "incômodo" na comunidade japonesa, regida pela imposição de uma hierarquia social muito rígida. Porém, esses episódios não interferiram na realização dos concursos, e a cada ano o número de inscritas aumentava.

O período de 1974 a 76 foi caracterizado por inovações no "Miss Colônia". No ano de 1974, o Jornal Paulista firma um acordo com o programa "Japan Pop Show" para televisionar o concurso através da TV Bandeirantes, o que, segundo Getúlio Kamiji, estimulou a participação das mulheres por iniciativa própria. Criado em 1973 com a intenção de oferecer à comunidade nikkei uma nova forma de entretenimento, o programa dominical, além da exibição do próprio concurso, realizava a apresentação das candidatas:

"O Japan Pop Show já há mais de um mês vem apresentando todos os domingos, as candidatas ao Miss Colônia 74 (...), de forma que a televisão vem ampliando a imagem do Miss Colônia por mais de 200 cidades do interior e outros estados" ${ }^{54}$.

Assim, com o desenvolvimento da mídia na colônia japonesa, o "Miss Colônia" passou a ser exibido em diversas cidades, o que estimulou a participação das "torcidas organizadas" que, se não estavam presentes no auditório, estavam na frente da televisão torcendo pela candidata de sua cidade ou associação. E, nos anos de 1974 e 75, justamente por se iniciar a transmissão do concurso, ele passa a ser gravado nos estúdios da TV Bandeirantes, com apresentação de Nelson Matsuda e Suzana Okamura.

Essa maior divulgação do concurso atraiu, sem dúvida, mais patrocinadores. Além da colaboração do "Japan Pop Show", contou-se com o patrocínio da Nissei S/A Indústria e Comércio, Amino, Nippotur, H. Stern, Turismo Fuji, Banco Mitsubishi Brasileiro S/A, Casa Columbia, Valisére (que fornecia os maiôs para o desfile), Osaka Hotel, etc. A loja de cosméticos Ikezaki ofereceu espaço para os preparativos das candidatas, e foi lá que, em 1974, a Max Factor do Brasil e a Escola Profissional de Cabeleireiros Teruya cuidaram da maquiagem e do penteado das candidatas.

Nesse ano, o número de participantes somou os 30, e "a maioria das candidatas inscritas (...) são as que venceram as eliminatórias nas suas respectivas regiões através de concursos públicos com a participação de representantes do Jornal Paulista." 55

54. Jornal Paulista, 17 de abril de 1974.

55. Idem 
Dessa forma, a pré-seleção das candidatas por região estava se transformando em um evento grandioso dentro de cada colônia japonesa no Brasil.

Entretanto, os realizadores do concurso tinham um objetivo maior. Com a idéia inicial de promover a integração entre as comunidades japonesas e as mulheres nikkeis, e com a grande aceitação do certame na colônia japonesa do Brasil, o Jornal Paulista lança a idéia de internacionalização do concurso em 1975:

“' 'Miss Internacional' - Para o próximo ano deverá apresentar-se candidatas de outros países. Argentina e Peru, através dos presidentes da Associación Japonesa de la Argentina e AELU-Associación Esportiva la Union prontificaram-se a enviar suas candidatas para o concurso do próximo ano, que poderá ser o primeiro internacional da América do Sul" 56.

Apesar do anúncio, a realização do "Miss Nikkei Internacional" 57 não se concretizou imediatamente. Em 1976 o concurso recebe duas candidatas argentinas da Associación Japonesa en la Argentina, Isabel Matsubara e Roxana Kawakita, mas elas não chegam a participar da seleção, apenas desfilam junto com as demais candidatas. Nakano Mitsuo, um dos organizadores do concurso, registra: "Neste ano vieram alguns nikkeis argentinos, e era justo a época de realização do Miss Colônia, (...) e parece que a Argentina também já estava realizando a eleição de misses, e as rainhas, primeira e segunda colocada, também vieram para cá. Como era uma oportunidade rara, ao invés delas apenas assistirem ao concurso (...), pedimos que subissem ao palco para um cumprimento. (...) Assim, as duas falaram em espanhol e o público aplaudiu e ficou muito feliz. O concurso miss em qualquer país é igual, e os nikkeis têm a mesma característica facial, então todos ficaram contentes." 58

Após esse episódio, a comissão de organização do concurso fez uma reunião para pedir o envio de candidatas a outros países. O primeiro passo foi entrar em contato com os jornais nikkeis do exterior para pedir a colaboração e a divulgação do concurso do Jornal Paulista. Assim, jornais como Peru Shimpô e Rafu Shimpô (Los Angeles), dentre outros, se encarregavam da divulgação e do envio da candidata ao Brasil. A internacionalização é efetivada em 1977, quando o concurso contou com a participação de candidatas vindas do Canadá, Estados Unidos, México, Paraguai, Peru e Argentina, somando sete nikkeis do exterior.

56. Jornal Paulista, 25 de fevereiro de 1975.

57. A fase internacional do concurso surgiu inicialmente com o nome "Miss Colônia Internacional". O nome muda para "Miss Nikkei Internacional" em 1978, segundo pôde ser verificado nas publicações do Jornal Paulista.

58. Traduzido do japonês e adaptado de entrevista. 
Assim como no concurso nacional, havia a pré-seleção das candidatas por associação ou região e os países participantes também realizavam os concursos de miss regionais para enviar a vencedora ao Brasil, a fim de participar do "Miss Nikkei Internacional". Nesse ano, Los Angeles escolheu sua candidata no "Japanese Week Festival", uma festa promovida pela colônia japonesa que também elegia a "Miss Japanese Festival"; o Paraguai enviou a "Miss Paraguai" eleita pela Federación de Associación Japonesa en el Paraguai em um concurso interno; o Canadá realizou a escolha da "Miss Nissei" na ocasião da comemoração do centenário da imigração japonesa; a colônia do México promoveu seu primeiro concurso de beleza para enviar uma representante ao Brasil e o Peru selecionou a candidata através da AELU.

Com a internacionalização do concurso, além da análise da beleza do rosto, da perfeição física, graça, personalidade e desembaraço social na ocasião do julgamento, acrescentou-se mais um item no regulamento de 1977: "conhecimento da língua japonesa ou inglesa para efeito de viagem ao Japão" ${ }^{59}$. E, nesse mesmo ano, houve algumas alterações na categorização das candidatas e o concurso passou a ser apresentado de forma distinta. No dia da competição, primeiramente se realizava o "Miss Colônia" entre as candidatas nacionais e, entre elas, cinco eram selecionadas para se juntar às candidatas internacionais e participar do "Miss Nikkei Internacional". Assim, a categorização ficou definida da seguinte maneira: seria eleita a "Miss Colônia" (e duas princesas), a "Miss Nikkei Internacional" (e duas princesas) e a "Miss Simpatia". Além disso, criou-se a eleição da "Miss Fantasia", para a qual cada candidata desfilaria com um traje típico de seu país.

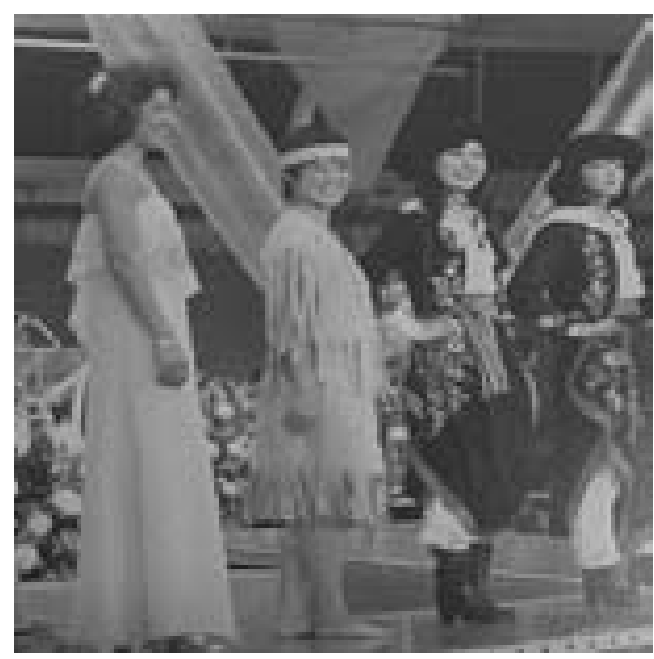

Desfile de fantasia das candidatas ao "Miss Nikkei Internacional 1977" (Fonte: Museu da Imigração Japonesa no Brasil)

59. Jornal Paulista, 11 de fevereiro de 1977. 
"Miss Colônia" e "Miss Nikkei Internacional" eram premiadas com passagens para o Japão, enquanto as demais candidatas eram contempladas com viagens pelo Brasil e diversos prêmios como jóias e roupas.

Até essa altura, o concurso havia adquirido uma dimensão muito ampla e o auditório da TV Bandeirantes já não comportava mais o público, até que, em 1976, ele passou a ser realizado no Palácio das Convenções no Anhembi. Assim, em 1977, Maris Estella Sotoma, uma mestiça argentina, é eleita a primeira "Miss Nikkei Internacional" e Sueli Yasuko Kakuda é premiada "Miss Colônia".

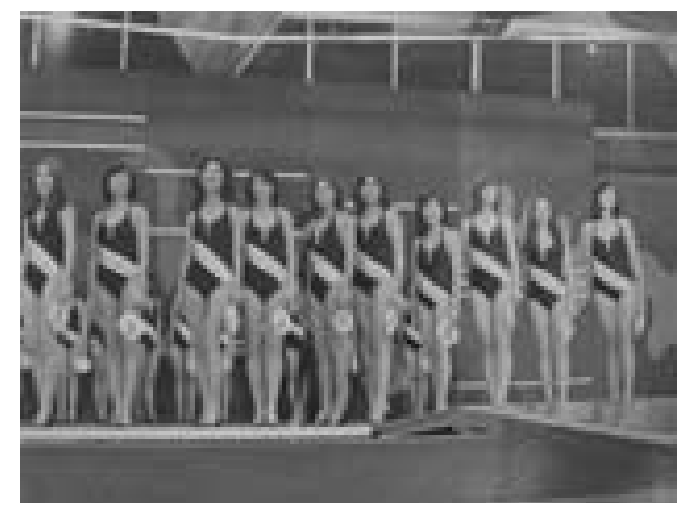

Desfile das candidatas ao "Miss

Colônia" e "Miss Nikkei" de 1977

(Fonte: Museu da Imigração Japonesa no Brasil)

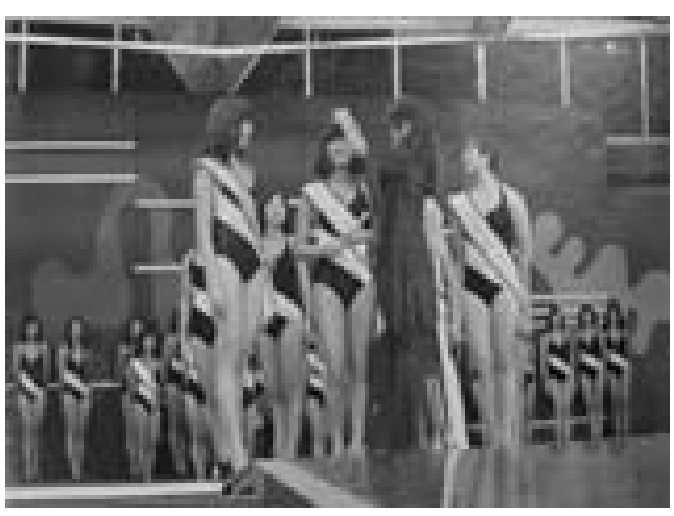

Premiação das candidatas internacionais de 1977 (Fonte: Museu da Imigração Japonesa no Brasil)

A transnacionalização do concurso foi um momento muito significativo, pois resultou numa dinamização do intercâmbio entre as colônias japonesas do Brasil e do exterior. No Brasil, o interesse pelo concurso aumentou, recebendo a participação de Curitiba, Porto Alegre, Minas Gerais, Amazonas, Amapá, Pará, Santa Catarina, Paraná e também do estado de São Paulo. No exterior, as colônias passaram a se reunir exclusivamente para a escolha da candidata a ser enviada ao concurso. Luiz Tanigaki, ex-diretor presidente do Jornal Paulista, em relação a essa nova fase do concurso, afirma que:

"o nosso objetivo é buscar o congraçamento social e cultural através do certame (...) e nós estamos reunindo neste acontecimento todas essas colônias, irmanando corações, conhecendo anseios, detalhando fatos históricos e coligindo impressões. (...) Não buscamos rendimentos, buscamos apenas o congraçamento social e cultural que essas lindas participantes estão tornando possível. " 60

Entretanto, pode-se dizer que o concurso não possuía apenas a função de integração cultural e social entre as candidatas. Havia também um sentido comercial

60. Jornal Paulista, 2 de junho de 1977 
muito forte. Principalmente após o início da realização do concurso internacional, o número de patrocinadores e colaboradores sofreu grande aumento e, além das empresas já mencionadas, a Sanyo do Brasil, a Yakult S/A, a Indústria de Óleo Pacaembu, Aeroperu Linhas Peruanas, o Hotel Nobilis, a Vasp e a Ótica Lapa passaram a fazer parte da equipe ${ }^{61}$. E é em 1977 que a patrocinadora mais importante do concurso surge: a Kodak do Brasil. Mais tarde, em 198362, a Kodak entra como promotora do evento e o Jornal Paulista passa a ser o realizador. A partir de então, a Kodak se torna o grande pilar de sustentação do concurso, anualmente concedendo verba para as despesas com passagem aérea das candidatas internacionais e suas acompanhantes e a viagem ao Japão das candidatas vencedoras, renovando o contrato de cinco em cinco anos.

Segundo Paulo Ogawa e Nakano Mitsuo, o concurso foi também um espaço para uma integração política entre os países participantes. As candidatas ao concurso geralmente vinham acompanhadas por representantes de sua associação ou por representantes dos jornais nikkeis de sua região e, enquanto elas se preparavam para o concurso, tais representantes também tinham a oportunidade de trocar informações. A partir desse intercâmbio, nasceu a Associação Pan-Americana Nikkei que realizava, congressos mundiais com representantes de diversas comunidades japonesas do exterior para discutir a situação social e econômica da colônia nikkei.

De certa forma, pode-se dizer também que, através dos concursos do Jornal Paulista, a relação política Brasil-Japão também foi intensificada. A candidata vencedora do "Miss Colônia" era encarregada de levar uma saudação do governo brasileiro ao governador ou prefeito das cidades irmãs de São Paulo. Em 1975, o Jornal Paulista publicou uma dessas mensagens:

"Com satisfação cumprimentamos, através da Srta. Marly Setsuko Matsuura, Miss Colônia 75, o povo da Cidade Irmã, Ôsaka. Estamos certos de que o permanente relacionamento entre brasileiros e japoneses permita a manutenção dos firmes laços de amizade que une nossas duas pátrias. "63

Dessa forma, a década de 70 foi a época definidora dos rumos do concurso realizado pelo Jornal Paulista. A transmissão pela televisão através do "Japan Pop Show", a realização no Anhembi e a internacionalização marcaram o concurso até o seu final, em 1994.

61. A entrada e a saída de patrocinadores ao longo do concurso foram muito constantes, não sendo possível citar com precisão todos aqueles que participaram.

62. O ano de transição de "patrocinadora" para "promotora" da Kodak não é preciso.

63. Jornal Paulista, 3 de julho de 1975. 


\subsubsection{Década de 80 a 90 - De amador a profissional}

A terceira e última fase, apesar de englobar o fim dos concursos, é marcada como o auge do "Miss Colônia" e "Miss Nikkei". O número de participantes bateu o seu recorde, os patrocínios surgiam em massa e o concurso chegou a ser transmitido por dois canais televisivos, atraindo as atenções do Japão para a beleza da mulher nikkei brasileira. Essa fase ilustrou de forma mais clara a transformação do perfil das mulheres descendentes de japoneses.

A partir da década de 60 , já havia se iniciado na colônia japonesa um gradual processo de diversificação profissional, ou seja, o afastamento da lavoura e o deslocamento para as capitais com vistas a proporcionar aos filhos melhor nível educacional fizeram com que o número de nikkeis formados em nível superior crescesse aceleradamente ${ }^{64}$. A princípio, a escolha do curso superior recaía principalmente sobre as profissões das áreas de ciências exatas ([como] Engenharia, Matemática), seguindo-se as áreas biomédicas (Medicina, Odontologia) e por último as ciências humanas (Letras, Ciências Sociais) ${ }^{65}$. A opção por profissões ligadas à área de exatas se deve à idéia de que facilitam a "ascensão social e, simultaneamente, asseguram melhor remuneração" ${ }^{66}$. Esse processo de assimilação profissional na sociedade brasileira prosseguiu durante a década de 70 , período em que se observa também a acentuação da entrada dos estudantes descendentes de japoneses "em cursos de letras, psicologia, biologia, astronomia, meteorologia, geografia, geologia, paleontologia, etc, (...) o que possibilitou a diversificação profissional, com expansão de nikkeis em todos os setores de atividade do país" ${ }^{\text {67. }}$.

Concomitantemente ao processo de inserção profissional do nikkei na sociedade brasileira, na década de 80 , de modo geral, se observa "um lento, porém intenso e consistente processo de transformação e incorporação feminina no mercado de trabalho"68, incorporação esta que não se restringe às áreas de trabalho consideradas "femininas", como a enfermagem, alcançando áreas que exigem maior qualificação.

Na década de 70, a mulher já havia conquistado maior escolaridade em relação aos homens, e na década de 80 passa a ocupar maior porcentagem dos postos

64. Na pesquisa realizada pela Beneficência Nipo-Brasileira de São Paulo em 1978, a porcentagem de agricultores, que em 1958 abrangia 58\% da população japonesa no Brasil, havia caído para 19,3\% - Comissão de Elaboração da História dos 80 anos de Imigração Japonesa no Brasil, op.cit., p.435

65. MIYAO, Sussumu. "Posicionamento social da população de origem japonesa" IN: A presença japonesa no Brasil, São Paulo, Edusp, 1980, p.94-95

66. Idem, p.95

67. Comissão de Elaboração da História dos 80 anos de Imigração Japonesa no Brasil, op. cit., p.435

68. www.seade.gov.br/produtos/mulher/index.php?bole $=0$ 
de trabalho, podendo-se dizer que a qualificação profissional feminina acabou adquirindo "(...) uma legitimidade social na mesma proporção do desapreço pelo modelo da mulher do lar"69. O seu papel social na década de 50 era reconhecido apenas pelas funções de mãe e esposa, agora, o trabalho passou a proporcionar um suporte muito importante de sua identidade social ${ }^{70}$, desenvolvendo-se uma "autonomia do sujeito feminino" à medida que sua identidade profissional foi se construindo.

Esse processo de inserção no mercado de trabalho e a elevação do nível educacional conseqüentemente favoreceram a concretização da inserção da mulher nikkei no mercado de trabalho, fato que claramente pode ser ilustrado pelas escolhas profissionais das candidatas aos concursos de miss. Ao se analisar algumas publicações da revista Miss Colônia e Miss Nikkei Internacional e diversas fichas de inscrição das candidatas aos concursos, em que está registrada a sua formação, de maneira geral, é possível constatar os seguintes dados ${ }^{71}$ : do total de 157 candidatas, contrariando o fenômeno inicial de concentração de estudantes nikkeis na área de exatas, 66,8\% freqüentavam os cursos da área de humanas, sendo que a carreira mais recorrente entre as candidatas era Direito, seguida por Psicologia e Administração. A área biológica representou cerca de $26,7 \%$ das profissões escolhidas pelas candidatas, sendo a Odontologia o curso mais freqüente, além de Farmácia, Enfermagem, Nutrição e Biologia, entre outros. Por fim, apenas 6,3\% das candidatas ao "Miss Colônia" e "Miss Nikkei" estavam se graduando na área de exatas, porcentagem essa que se diluía entre diversos cursos como Ciências Contábeis, Engenharia (Química, Elétrica) e Economia.

A abertura do mercado de trabalho para a profissional feminina e também a estabilidade alcançada pelos japoneses no Brasil possibilitaram à mulher nikkei a formação de uma carreira, enfraquecendo-se cada vez mais a imagem da mulher subserviente dedicada apenas aos afazeres domésticos.

Em contrapartida, porém, Getúlio Kamiji diz que muitas das candidatas na década de 80 ainda tinham como objetivo de vida o casamento, e, através dos concursos de beleza, diversos relacionamentos acabaram se concretizando. Mas, de forma geral, fica evidente o grande salto na imagem da mulher nikkei em relação aos primórdios do concurso.

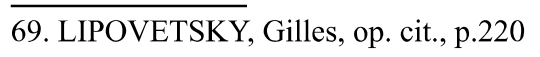

70. Idem, p.224

71. O levantamento de dados foi elaborado considerando os anos de 1984, 1986, 1987 e 1989 e levou em conta apenas as candidatas que cursavam nível superior, excluindo-se aquelas que freqüentavam cursinhos preparatórios e ensino médio. 
Junto com esse movimento de inserção das mulheres nikkeis na sociedade brasileira, o próprio "Miss Colônia" e "Miss Nikkei" lançou diversas tentativas de apresentar o concurso à sociedade brasileira através de programas populares de televisão, como conta Getúlio Kamiji:

“(...) o Paulo Ogawa resolveu levar [o concurso] para o Amaury Jr., no programa 'Flash Oriental' (...) e o Amaury abriu espaço dizendo: 'vamos colocar à noite na Record, ao vivo, direto?' (...) E foi nesse programa que teve grande repercussão entre o público ocidental".

Ainda segundo Getúlio Kamiji, a grande maioria dos brasileiros não tinha conhecimento dos concursos de beleza realizados na colônia japonesa, e muitas vezes ficavam surpresos ao descobrirem que os japoneses "também" promoviam tais concursos. Alguns jornais brasileiros, como o Diário Popular e o Estado de São Paulo, chegaram a divulgar notas sobre o concurso, mas, sem dúvida, ele recebeu maior destaque dentro da própria colônia japonesa.

No dia 26 de junho de 1985, o Jornal Paulista publicou o resultado de uma enquete intitulada "Beleza em discussão", que lançava duas perguntas: "O que pensam os descendentes sobre os concursos de beleza da colônia? Você assiste ao Miss Colônia e Nikkei Internacional?” Dos 24 entrevistados, 15 assistiam ao concurso todos os anos ou haviam assistido algumas vezes. Um estudante de 17 anos respondeu:

"Já assisti ao Miss Colônia e pelo que pude observar, o critério de avaliação da colônia ainda está voltado para o comportamento da pessoa (critérios de concursos da década de 50) e não exatamente para a beleza estética."

Outro estudante declarou que o que lhe chamava a atenção era o "corpo com curvas", característica típica da mulher brasileira. Ou seja, com o aumento da mestiçagem entre os japoneses (como já mencionado, na década de 80 , os casamentos interétnicos representavam quase $50 \%$ do total de casamentos), as características físicas da mulher nikkei conseqüentemente sofreram algumas alterações. O corpo tipicamente japonês ganhou traços curvilíneos e os olhos puxados tornaram-se amendoados. Segundo Getúlio Kamiji, se, na década de 50, todas as candidatas ao concurso eram descendentes puras, na década de 80 , a cada 10 candidatas, 8 eram mestiças. Essa nova figura estética da mulher nikkei atraiu grandes atenções do mercado publicitário japonês no final da década de 80 , o que será comentado posteriormente.

A imagem da mulher nikkei através dos concursos "Miss Colônia" e "Miss Nikkei" deu um grande salto especialmente em 1985, como lembram todos os organizadores do evento entrevistados. Nesse ano, a vencedora do título "Miss Nikkei" foi uma americana descendente de okinawanos, Tamlyn Tomita. Eleita a 
nikkei mais bonita através do "Nissei Week Japanese Festival", organizado em Los Angeles, Tamlyn surpreendeu a todos e levou o título de "Miss Nikkei", já que não estava entre as favoritas. Após a participação no concurso, Tamlyn passou a ser a divulgadora da beleza da mulher nikkei no mercado cinematográfico americano com a participação no filme Karate Kid. O cinema americano, responsável pela multiplicação de novas imagens femininas ${ }^{72}$, também incorporou a possibilidade de difusão da imagem da mulher nikkei numa grande escala, ainda que vista de modo estereotipado.

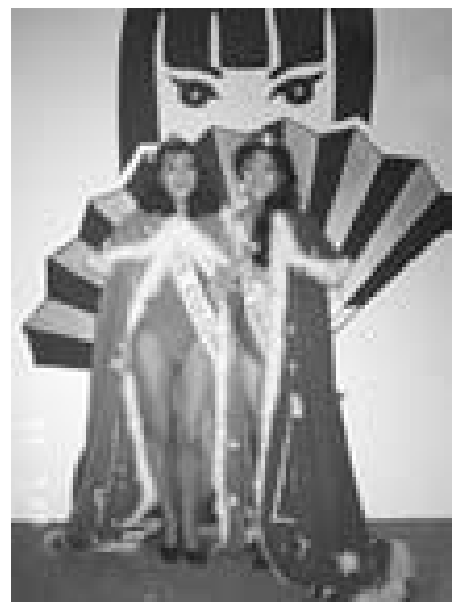

"Miss Colônia" Misawa

Kiyo e "Miss Nikkei" Tamlyn Tomita. (Fonte: Arquivo pessoal de Paulo Ogawa)

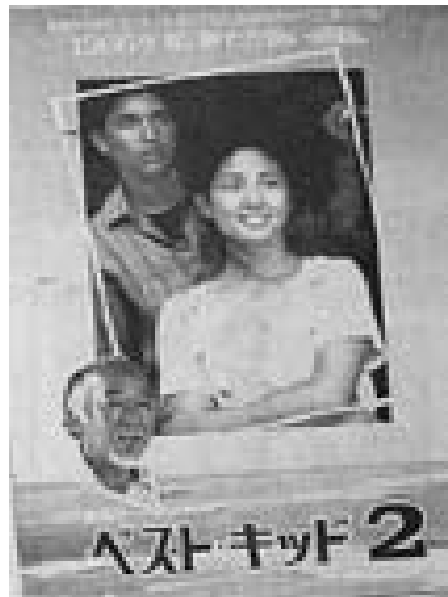

Pôster de divulgação do filme

Karatê Kid II. (Fonte:Museu

Histórico da Imigração

Japonesa no Brasil)

1985 foi um dos mais significativos para o concurso, já que nesse ano ocorreu o que se pode chamar de "intercâmbio de belezas". O corpo de jurados, como já mencionado, era composto por diversas personalidades da comunidade nikkei e também da sociedade brasileira. Desde 1982, Mário Covas e sua esposa presidiam o corpo de jurados do concurso, empresários nikkeis de todos os ramos empresariais e inúmeras outras figuras estavam presentes para a escolha das misses. Em 1985, esse corpo de jurados ganhou uma participação especial com a vinda da Miss Japão 85, Rika Kobayashi, e a participação da Miss Brasil 85, Márcia Gabrielle Canavezes. Márcia, além de sua participação como jurada, através do convite realizado pelo Jornal Paulista, fez uma visita ao Japão juntamente com a "Miss Colônia" e a "Miss Nikkei”, participando de diversos desfiles realizados em Tóquio e Ôsaka ${ }^{73}$. Lá,

72. PRIORE, Mary del. Corpo a corpo com a mulher - Pequena história das transformações do corpo feminino no Brasil, São Paulo, ed. SENAC, 2000. p. 74.

73. Jornal Paulista, 14 de dezembro de 1985. 
divulgou a beleza da mulher brasileira em diversos artigos de revistas japonesas, recebendo alguns convites de trabalho. Dessa forma, o concurso criou um espaço de intercâmbio entre duas belezas muito distintas e, principalmente, apresentou a mulher brasileira à sociedade japonesa, ganhando um sentido totalmente transnacional.

Estruturalmente, "Miss Colônia" e "Miss Nikkei" mantiveram-se os mesmos em relação à década de 70, porém, com a parceria estabelecida com a Kodak, em 1981 é criada uma nova categoria para o concurso, a "Miss Fotogênica". Essa categoria possibilitava à candidata ser contratada para trabalhar nas campanhas de divulgação publicitária da própria Kodak. ${ }^{74}$

Assim como nos anos anteriores, na semana antecedente ao concurso, as candidatas cumpriam uma agenda cheia de compromissos, visitando patrocinadores, indo a restaurantes e festas para promover o certame. O intervalo entre a chegada das candidatas a São Paulo e o dia do concurso não era apenas uma semana de espera, pois ocorria uma verdadeira maratona de intercâmbio cultural entre as nikkeis de diversas colônias do mundo e o concurso concretizava seus objetivos.

"Intercâmbio cultural" aqui se refere não apenas às trocas de informações entre as candidatas, mas ao concurso como um espaço que possibilitou a descoberta e o reconhecimento de uma identidade cultural comum, em maior ou menor grau, entre mulheres nikkeis criadas nas mais diversas localidades do Brasil e do mundo.

Embora muitos dos descendentes de japoneses no Brasil afirmem categoricamente "ser brasileiro", já que nasceram e se criaram neste país, diversos valores socioculturais japoneses inevitavelmente foram deixados como herança e internalizados, seja durante seu crescimento, seja no processo educacional. E essa co-existência de uma cultura minoritária e uma cultura dominante inúmeras vezes foi palco para o desencadeamento de um conflito interior. Nesse sentido, podese dizer que os concursos "Miss Colônia" e "Miss Nikkei" quebraram a barreira do conflito existente entre as mulheres nikkeis, especificamente, e a sociedade ocidental na qual vivem, e possibilitaram um reconhecimento identitário mútuo enquanto pessoas pertencentes a uma comunidade japonesa, independentemente do país em que ela esteja localizada.

Nakano Mitsuo, em sua entrevista, relata com emoção um dos episódios que considera como mais marcantes do concurso realizado pelo Jornal Paulista:

"Uma vez, quando o concurso já havia terminado (...) levamos as candidatas ao Rio,

74. O nome da categoria varia ao longo do concurso, ora surge como "Miss Kodak", ora como "Garota Kodak". 
e fizemos uma coisa divertida. Saímos daqui [de São Paulo] e fomos ao Rio de ônibus, pelo litoral, passando por Paraty e Angra até o centro, onde havia o hotel em que elas ficariam hospedadas. (...) Mas elas foram se cansando [da viagem] e uma menina que cantava muito bem, acho que era do Peru, começou a cantar uma canção infantil em japonês. E surpreendentemente, todas começaram a cantar a mesma música, ao acabar esta, começaram a cantar outra e se abraçaram fortemente. (...) E, como se sabe, cada uma falava uma língua, inglês, espanhol, português e japonês, mas todas sabiam cantar a canção infantil. E eu perguntei: com quem vocês aprenderam essas músicas? E elas disseram que aprenderam com suas avós e mães. Mas foi um episódio que me surpreendeu muito, elas choravam de felicidade (...) ao perceber que todas sabiam cantar as mesmas músicas". ${ }^{75}$

E esse reconhecimento entre as candidatas acabou estimulando também um auto-reconhecimento enquanto mulher descendente de japoneses. Em entrevista, a mestiça Cláudia Otonari Miura, segunda "Princesa Miss Colônia" do concurso de 1986, revela:

“(...) eu só despertei para a cultura [japonesa] e para o seu lado positivo depois do concurso, porque aí ficou mais evidente a minha descendência. (...) eu participava das atividades no clube [Santo Amaro Esporte Clube, pelo qual foi indicada ao concurso] porque tinha minha família, mas eu não era muito ligada à cultura japonesa. E a partir de então é que eu comecei a ter mais ligação. (...) Foi muito bom porque me descobri como japonesa depois dessa convivência maior, e o concurso foi o começo de tudo isso. (...) Depois eu comecei a freqüentar mais os restaurantes [japoneses], as festas, quando tinha na Liberdade, porque passei a me interessar mais. Como eu tive o lado brasileiro da minha mãe muito forte, eu também tenho o lado brasileiro muito mais forte, talvez, que o japonês. Mas eu comecei até a aprender japonês, porque achava o cúmulo as pessoas olharem para mim, com esse olho puxado, e não saber falar japonês".

Hoje, com dois filhos, Cláudia também tem a preocupação de transmitir alguns dos valores japoneses que passou a admirar após a participação no concurso, como a hierarquia dentro dos relacionamentos pessoais, o respeito aos mais velhos.

Assim, os concursos realmente foram um espaço de integração entre as candidatas e, além disso, uma oportunidade para o resgate de uma identidade japonesa que havia se perdido ao longo das gerações e em meio ao processo de inserção na sociedade brasileira. E, de certa forma, houve também uma valorização estética da beleza nipônica (ou da beleza oriental). Em 1986 uma candidata declarou: "Quando era pequena, achava feio [os traços orientais]. Hoje aprendi a gostar." 76

Essa valorização da mulher com traços orientais ficou evidente em 1987,

75. Traduzido do japonês e adaptado da entrevista.

76. Jornal Paulista, 4 de julho de 1987 
quando o Jornal Paulista fecha contrato com a agência de modelos japonesa "Urban". A partir daí, o concurso adquiriu um caráter profissional. Tal agência buscava especialmente a beleza da mulher nikkei mestiça. Tendo sido enviado um "olheiro" aos concursos, algumas candidatas, vencedoras de algum título ou não, fechavam contratos de trabalho de quase um ano no Japão. Aqui se concretiza a transformação da visão negativa que pairava sobre as mestiças nos anos $50 \mathrm{em}$ uma visão positiva dessa beleza peculiar, que acaba por conquistar os olhares do mercado japonês.

Tornando-se um concurso que oferece uma oportunidade profissional, o perfil das candidatas também se modificou. A partir da década de 90 , muitas das candidatas já possuíam experiência como modelo ou almejavam se tornar modelo, seguir uma carreira profissional na área, o que até a década de 80 não existia. Influenciadas ou não pelo boom do movimento decassegui, que teve seu início aproximadamente na segunda metade da década de 80 , muitas das candidatas aos concursos de miss foram ao Japão em busca de um sucesso profissional.

Abaixo, seguem algumas das campanhas japonesas realizadas pelas candidatas ao "Miss Colônia" e "Miss Nikkei” no Japão:

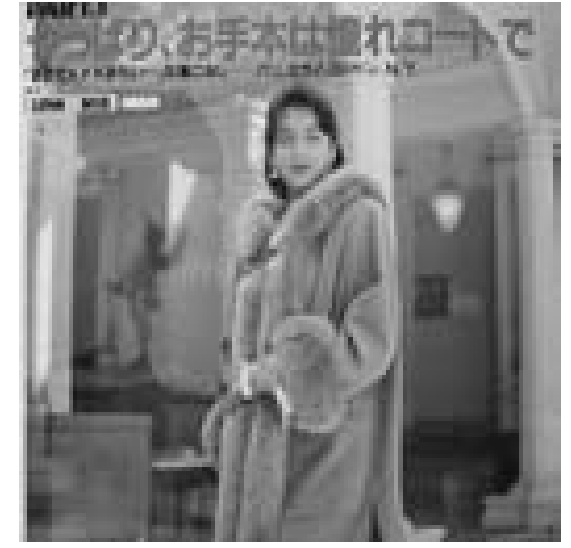

(Fonte: Arquivo pessoal de Paulo Ogawa)

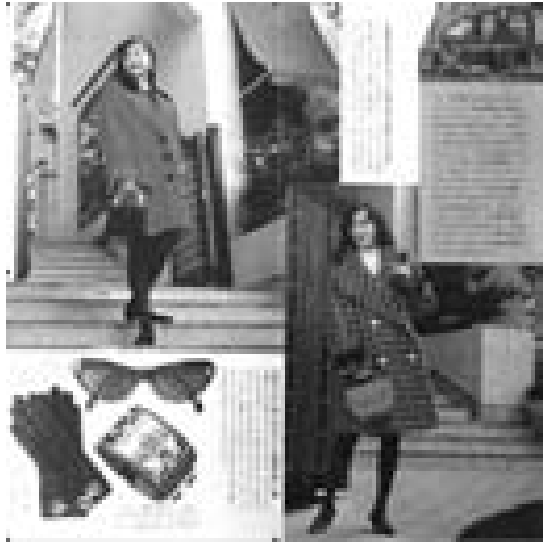

(Fonte: Arquivo pessoal de Paulo Ogawa)

Todavia, mesmo com todo o impulso conquistado pelo Jornal Paulista, pela sua força de atuação e divulgação da mulher nikkei, em 1994 o concurso inevitavelmente chegou ao fim. Segundo Paulo Ogawa, o principal motivo do término do concurso foi a suspensão do grande patrocínio da Kodak, que havia acompanhado o concurso durante mais de dez anos. A recessão que assolou o país no começo da década de 90 tornou insustentável o financiamento das inúmeras passagens aéreas e hospedagens em hotéis e nenhum outro patrocinador possuía condições de arcar com a imensa despesa. Dessa forma, ainda no auge de sua realização, é que o Jornal Paulista baixava as cortinas de mais de vinte anos de história. 


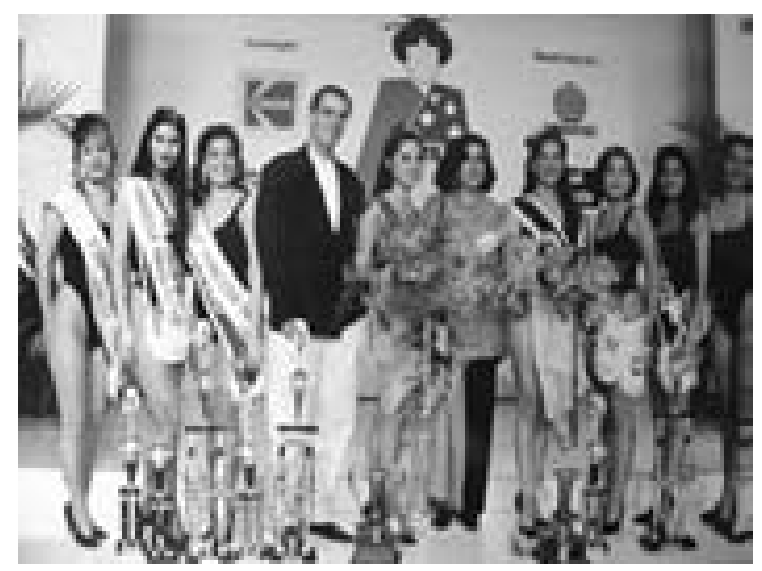

As vencedoras do último concurso "Miss Colônia" e "Miss

Nikkei”, em 1994. (Fonte: Arquivo pessoal de Paulo Ogawa)

\section{Uma visão panorâmica dos atuais concursos de beleza da comunidade japonesa no Brasil:}

Treze anos após o fim do "Miss Colônia" e "Miss Nikkei", a colônia japonesa continua realizando de forma constante os concursos de beleza, ainda que não tenham tamanho alcance como os do Jornal Paulista.

Pode-se dizer que hoje há um movimento de retorno à fase inicial dos concursos de beleza, ou seja, eles estão sendo realizados novamente com características regionais, seja dentro de festivais, seja como um evento independente. Segundo Kendi Yamai, promotor e organizador dos principais concursos de beleza atuais da colônia japonesa, muitas regiões, como Marília, Presidente Prudente, Maringá e Paraná, ainda realizam concursos de miss. Em São Paulo, além do "Miss Tanabata", promovido na Festa Tanabata, no bairro da Liberdade, os concursos de beleza que recebem maior destaque são o "Miss Festival do Japão" e o "Faces". O primeiro concurso está conjugado ao "Festival do Japão", evento anual realizado pela Associação das Províncias Japonesas no Brasil . A forma de seleção varia muito, segundo Kendi, e na sua quarta edição, em 2006, as candidatas passaram por duas fases de avaliação: se fez um desfile em traje social, e aquelas que foram escolhidas desfilaram novamente com yukatá. ${ }^{77}$

O concurso "Faces" teve início em 1995 com uma nova proposta. De caráter oriental, não mais se restringindo às candidatas descendentes de japoneses, mas abrangendo descendentes de asiáticos em geral, ele surgiu com o intuito de movimentar os jovens da colônia e oferecer uma oportunidade para as candidatas serem modelos, principalmente no Japão. De certa forma, ele possui um caráter profissionalizante, já que bookers e donos de agências japonesas vêm ao concurso

77. Yukatá é um tipo de quimono leve utilizado no verão. 
para avaliar as candidatas, e algumas saem com contrato fechado com as agências. Entretanto, o grande diferencial de "Faces" é que também possui uma versão masculina, fato inédito dentro dos concursos de beleza da colônia japonesa.

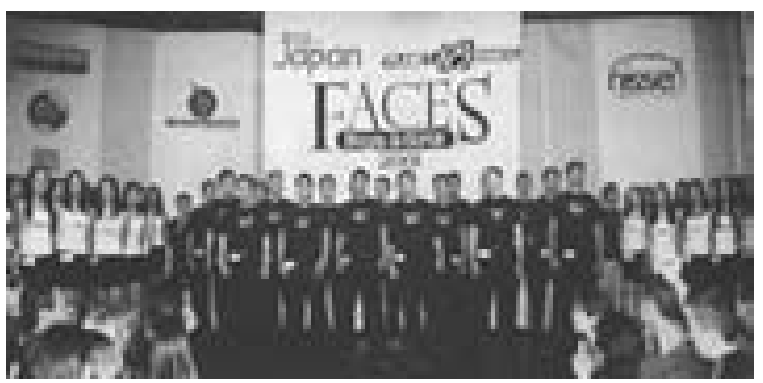

Candidatas e candidatos ao "Faces 2001". (Fonte: Museu Histórico da Imigração Japonesa no Brasil)

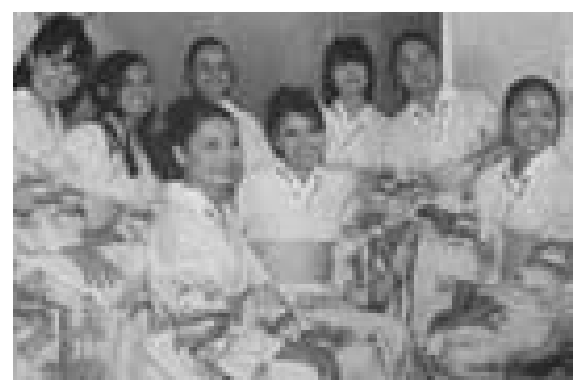

Candidatas ao "Miss Festival do Japão 2006" (Fonte: Museu Histórico da Imigração Japonesa no Brasil)

Seguindo a tendência observada já nos concursos do Jornal Paulista, a participação de mestiças está cada vez maior e, com a inserção dos descendentes de japoneses na mídia brasileira, Kendi acredita que o estereótipo pregado por muito tempo está desaparecendo, perdendo força o "clichê da 'japinha"”.

Apesar do mercado japonês buscar a beleza da mulher mestiça, nem sempre é possível para a vencedora do concurso seguir uma carreira no Japão, pois a beleza eleita no Brasil muitas vezes não está dentro dos padrões japoneses. Kendi explica da seguinte maneira:

"às vezes, a vencedora não tem muito o perfil [japonês], ela é bonita para o Brasil, mas para o mercado japonês não funciona. Então, a gente percebe que têm modelos que dão certo aqui, e outras que dão certo lá. (...) A beleza japonesa, para o mercado japonês, asiático, é aquela que tem um rosto meigo e um corpo fino. No caso ocidental, a mulher possui mais sex-appeal, é cheia de curvas."

Por outro lado, é interessante notar a proliferação dos concursos de beleza dentro das comunidades brasileiras no Japão. Em Aichi, na cidade de Komaki, Daniela Nishikawa promove desde 2002 o "Miss Nikkey", concurso de beleza voltado para brasileiras descendentes de japoneses residentes no Japão. Junto com o concurso, se realiza também o "Festival Brasileiro", evento gratuito constituído por diversas atrações como apresentações musicais, teatrais, esportivas e dança, dentre outras. ${ }^{78}$

O objetivo do "Miss Nikkey" é proporcionar a chance de inserção no mercado

78. http://tudobem.uol.com.br/2007/04/01/tudo-pronto-para-o-miss-nikkey-2007 
de moda japonês. O concurso já é considerado "o acontecimento tradicional brasileiro no Japão" e, segundo Daniela:

"é mais que um concurso de beleza, o Miss Nikkey é o resgate de uma tradição nipobrasileira e também o congraçamento entre candidatas, familiares e torcidas organizadas de diversas localidades. A comunidade brasileira no Japão é carente de atividades de lazer e principalmente em se tratando de eventos gratuitos. Por isso tem sido maior a cada ano. (...) $)^{\prime \prime 9}$

O evento vem atraindo também grande massa de patrocinadores brasileiros e japoneses, sendo também um momento de "congraçamento do empresariado que participa da festa". 80

Há ainda inúmeros concursos de beleza realizados na comunidade nikkei brasileira. Nota-se que atualmente, tanto no Brasil como no Japão, os concursos ainda são realizados com um intuito de promover a integração dos membros da comunidade nikkei e alguns ganham força pelo seu caráter profissional, influenciado talvez pelo glamour com que a profissão de modelo vem instigando a sociedade.

\section{Considerações finais:}

As mulheres descendentes de japoneses passaram por uma verdadeira saga desde a sua chegada ao Brasil em 1908. Enfrentaram o trabalho longo e árduo nas lavouras, a impossibilidade de acesso aos estudos, a submissão ao homem e à família, o posicionamento entre o modelo ideal de mulher japonês e brasileiro, a dificuldade de inserção no mercado de trabalho, a discriminação em relação à mestiçagem e o preconceito contra o casamento interétnico.

Entretanto, com a decisão de fixação no Brasil, a mulher nikkei passou por um intenso processo de assimilação na sociedade brasileira, processo que se refletiu parcialmente nos concursos de beleza.

Os certames regionais realizados desde a década de 40, assim como o "Miss Colônia" e o "Miss Nikkei Internacional", foram concursos pioneiros não apenas por serem os primeiros promovidos na colônia japonesa do Brasil, mas justamente por trazer à luz a discussão sobre a questão da mulher nikkei, que até então se camuflava em meio às figuras masculinas.

Nos anos 50, o "Miss Colônia" surgiu com uma nova forma de olhar para a

79. www.brazil.ne.jp/contentes/newsinjapan/newsinjapa001_2004041310.htm

80. www.brazil.ne.jp/contentes/newsinjapan/newsinjapa001_2004041310.htm 
mulher nikkei, desafiou valores e, apesar das dificuldades enfrentadas para a sua realização, teve grande importância e na década de 70 pôde ser realizado de forma muito mais ampla.

A partir dos anos 70, já com o passar dos anos e a maior abertura sócioeconômico-cultural da colônia japonesa, a mulher nikkei inevitavelmente sofreu diversas transformações, seu objetivo de vida já não era mais freqüentar as "escolas de noiva", se casar e constituir uma família. Aos poucos ela foi incorporando uma identidade profissional e surgiu o desejo de formar uma carreira. Com isso, gradualmente foi se desligando da imagem estereotipada da mulher submissa e recatada, ganhando independência e sendo reconhecida enquanto profissional. $\mathrm{O}$ concurso foi um espaço que possibilitou o reconhecimento e a aceitação, mesmo que parcial, da evolução da mulher nikkei e sua inserção na sociedade brasileira.

O concurso também trouxe à tona a questão da mulher nikkei mestiça, abriu espaço para ela e, na década de 80 , as mestiças já eram maioria nos concursos e sua imagem sofreu grande transformação, sendo valorizada não apenas no Brasil, mas também pelo mercado publicitário japonês, que avidamente buscava a beleza da mulher mestiça.

Todavia, "Miss Colônia" e "Miss Nikkei" vão além disso. Eles realmente promoveram aquilo que desde o início se chamou de "integração" tanto das comunidades japonesas nacionais e internacionais, como das próprias candidatas, que muitas vezes acharam nos concursos uma oportunidade para redescobrir a sua identidade japonesa e compreender com outros olhos a cultura japonesa.

$\mathrm{O}$ seu impacto não se restringiu às comunidades japonesas. Como lembra Cláudia Otonari Miura, “os japoneses eram vistos como 'os estudiosos', aqueles que eram melhores tecnologicamente, mas hoje em dia, os próprios brasileiros têm visto com outros aspectos a cultura japonesa, descobrindo a culinária, a beleza e seus valores fora do padrão só do conhecimento, como era antigamente".

Dessa forma, "Miss Colônia" e "Miss Nikkei" deixaram como herança a importância do resgate da cultura japonesa entre seus descendentes e trouxeram à tona o processo de transformação e assimilação da mulher nikkei, seja na comunidade japonesa, seja na sociedade brasileira. E, atualmente, se observa uma movimentação contrária: a realização dos concursos de beleza nas comunidades brasileiras no Japão para inserir no mercado de trabalho as brasileiras descendentes de japoneses que lá residem e criar uma integração entre os membros brasileiros dessas comunidades.

Ao longo desta pesquisa, observou-se a grande necessidade de resgatar a trajetória da mulher nikkei, a transformação de sua imagem ao longo das décadas e a sua contribuição para a constituição da comunidade japonesa brasileira. Em 
2008, se completará o ciclo de cem anos desde a chegada dos primeiros imigrantes japoneses ao Brasil, mas pouco se tem discutido sobre a questão da mulher nikkei no Brasil, e o reconhecimento de seu papel enquanto parte constituinte da história da imigração japonesa ainda está em sua fase inicial.

\section{Bibliografia:}

ACCIOLI, Roberto B. \& TAUNAY, Alfredo D'E.. História geral da civilização brasileira - das origens à atualidade, Rio de Janeiro, Bloch Edições, 1973. BASSANEZI, Carla. Mulheres nos Anos Dourados, In: Priore, Mary del (org) História das mulheres no Brasil, São Paulo, ed. Contexto, 2001, p.607-639.

CARDOSO, Ruth C. L.. Estrutura familiar e mobilidade social: estudo dos japoneses no Estado de São Paulo, São Paulo: Kaleidos-Primus Consultoria e Comunicação Integrada S/C Ltda, 1998, p.29-112.

Comissão de Elaboração da História dos 80 anos de Imigração Japonesa no Brasil - Uma epopéia moderna: 80 anos de imigração japonesa no Brasil, São Paulo, HUCITEC: Sociedade Brasileira de Cultura Japonesa, 1992.

Comissão de Recenseamento da Colônia Japonesa 1964 - The Japanese Immigrants in Brazil, Tokyo, University of Tokyo Press.

Consulado Geral do Japão, O japonês em São Paulo e no Brasil, São Paulo 1971.

DEMARTINI, Zeila de Brito Fabri. Relatos orais de famílias de imigrantes japoneses: elementos para a história da educação brasileira, Educ. Soc. Vol 21, $\mathrm{n}^{\circ}$ 72, Campinas, Aug. 2000

GIULIANI, Paola Cappellin. "Os movimentos de trabalhadores e a sociedade brasileira”, In: Priore, Mary del (org) História das mulheres no Brasil, São Paulo, ed. Contexto, 2001, p. 640-665.

HANDA, Tomoo. "Geografia das seis fazendas" (Lavouras em que foram distribuídos os imigrantes), In: O imigrante japonês, história de sua vida no Brasil, São Paulo, T.A Queiroz, Editor/Centro de Estudos Nipo-Brasileiros, 1987, p.19-21.

HAYNES, Avelina Salles. A mulher japonesa no Brasil, In: Consulado Geral do Japão, O japonês em São Paulo e no Brasil, São Paulo, 1971, p.211-219.

HIRATA, Helena. "Trabalho, família e relações homem/mulher - reflexões a partir do caso japonês", In: Revista Brasileira de Ciências Sociais, São Paulo: ANPOCS, n 2, v. 1, 1993, p.5-12.

KIYOTANI, "Masuji. Ko no ishukon to konketsu no mago", In: Burajiru Nikkei 
Koronia Bungei, São Paulo, Centro de Estudos Nipo-Brasileiros, ed. Toppan Press, 2006, p. 65-78.

LEWENHAK, Sheila. A mulher e o trabalho, Lisboa, Editorial Presença Ltda., 1983.

LIPOVETSKY, Gilles. A terceira mulher - permanência e revolução do feminino, Maria Lúcia Machado (trad), São Paulo, Companhia das Letras, 2000.

MORI, Koichi. Burajiru no Nihonjin to Nihongo (Kyôiku) Os japoneses e a Língua Japonesa (ensino) (In) Revista Mensal Kokubungaku Kaishaku to kanshô (Literatura Nacional - Interpretação e Leitura) 2006.7 Vol.71. No.7, p.6-47.

NOGUEIRA, Arlinda Rocha. A imigração japonesa para a lavoura cafeeira paulista (1908-1922), Instituto de Estudos Brasileiros da Universidade de São Paulo, São Paulo, 1973.

NOMURA, Tânia. Universo em segredo: a mulher nikkei no Brasil, São Paulo, Círculo do Livro S.A, 1990.

OGAWA, Felícia Megumi. "Problemas de identidade sócio-cultural no Brasil". In: Cadernos, $\mathrm{n}^{\circ} 16,1^{\circ}$ série, novembro de 1981, Centro de Estudos Rurais e Urbanos, São Paulo, pp.19 32.

PRIORE, Mary del (org). História das mulheres no Brasil, São Paulo, ed. Contexto, 2001, pp.607 672.

Corpo a corpo com a mulher - Pequena história das

transformações do corpo feminino no Brasil, São Paulo, ed. SENAC, 2000.

QUEIROZ, Renato da S.. O corpo do brasileiro - estudos de estética e beleza, São Paulo, ed. SENAC, 1999.

Relatório de pesquisa da Comunidade Nikkei, Centro de Estudos Nipo-Brasileiros, 2002.

SAITO, Hiroshi (org). A presença japonesa no Brasil, São Paulo, EDUSP, 1980.

SUZUKI, Teiichi. "Mobilidade geográfica de imigrantes japoneses", IN: Consulado Geral do Japão, O japonês em São Paulo e no Brasil, São Paulo 1971, p. 92103.

TELLES, Lígia Fagundes. "Mulher, mulheres" In: Priore, Mary del (org) História das mulheres no Brasil, São Paulo, ed. Contexto, 2001, p.669-672.

TONGU, Érica A. S. Resistência de Seda: um estudo preliminar sobre a nacionalização dos imigrantes japoneses e a educação no Brasil, Dissertação de mestrado, Universidade de São Paulo, 2002, p.84-117.

TRIGO, Maria Helena Bueno. A mulher universitária: códigos de sociabilidade e relações de gênero, In: BRUSCHINI, Cristina \& SORJ, Bila (orgs) Novos olhares: mulheres e relações de gênero no Brasil, São Paulo, Marco Zero, Fundação 
Carlos Chagas, 1994, p. 89-110.

ZENPATI, Ando \& WAKISAKA, Katsunori. "Sinopse histórica da imigração japonesa no Brasil”, IN: Consulado Geral do Japão, O japonês em São Paulo e no

Brasil, São Paulo 1971, p.4-40.

Jornais consultados:

- Jornal Paulista: todas as edições desde 1950 até 1994.

- São Paulo Shimbun : "Primeiro casal nipo-brasileiro de SP pode ter surgido há 80 anos", ano 51, n 11.473, 17 de julho, 1998.

- Anuário do Jornal Paulista: década de 50 até a edição de 1995.

Revistas consultadas:

- Revista Arigatô:

- Ano 1, n 5, abril, 1977

- Ano 1, $\mathrm{n}^{\circ}$ 7, junho, 1977

- Ano 1, n 8, agosto, 1977

- Revista Miss Colônia e Miss Nikkei Internacional: edições de 1984, 1987, 1989, 1990, 1991 e 1992.

- Anuários do Jornal Paulista: edições de 1953 a 1995.

\section{Entrevistas:}

06/06/06 - Entrevista com Sr. Nakano Mitsuo.

20/09/06 - Entrevista com Sr. Paulo Ogawa.

23/10/06 - Entrevista com Sr. Getúlio Kamiji.

11/01/07 - Entrevista com Cláudia Otonari Miura.

27/02/07 - Entrevista com Inês Ogata, concedida via e-mail.

08/03/07 - Entrevista com Kendi Yamai.

Sites consultados:

- www.brazil.ne.jp/contentes/newsinjapan/newsinjapa001_2004041310.htm

• http://tudobem.uol.com.br/2007/04/01/tudo-pronto-para-o-miss-nikkey-2007

- www.brazil.ne.jp/contentes/newsinjapan/newsinjapa001_2004041310.htm

- www.missnikkey.com

- www.fcc.org.br/mulher.presbd.html

- www.yushima.net/contiti/soturon

Anexo:

Lista das vencedoras baseada no Anuário Paulista e em diversas edições do Jornal Paulista*: 


\begin{tabular}{|c|c|}
\hline $\begin{array}{c}1957 \\
\text { (Realizado no } \\
\text { quarto andar do } \\
\text { prédio sede do } \\
\text { Jornal Paulista) }\end{array}$ & $\begin{array}{l}\text { Miss Colônia: Geny Toshie Fukuda (Lins) } \\
\text { Princesas: 1.Ikeda Toshiko (Assai) } \\
\text { 2. Nakano Shôko (Suzano) }\end{array}$ \\
\hline $\begin{array}{c}1959 \\
\text { (Realizado no Cine } \\
\text { Niterói) }\end{array}$ & Miss Colônia: Fujino Utako (São Paulo) \\
\hline $\begin{array}{l}1973 \\
\text { (Realizado no } \\
\text { Bunkyo) }\end{array}$ & $\begin{array}{l}\text { Miss Colônia: Rosa Maria Fukugawa (Marília) } \\
\text { Princesas: Celina Arima (Indianópolis) } \\
\text { Margarete Ide (Anhangüera) } \\
\text { Takayo Hamada (Araçatuba) } \\
\text { Mikiko Tokumoto (Lins) }\end{array}$ \\
\hline $\begin{array}{l}1974 \\
\text { (Realizado no } \\
\text { teatro da TV Ban- } \\
\text { deirantes) }\end{array}$ & $\begin{array}{l}\text { Miss Colônia: Amélia Megumi Yokoo (Ourinhos) } \\
\text { Princesas: Luísa Tokiko Yanagibashi (Tomé Assú) } \\
\text { Marie Kuroki (Araçatuba) } \\
\text { Helena Fumiko Arihara (Cocuera) } \\
\text { Fátima Regina Barros Efuji (Minas Gerais) } \\
\text { Miss Simpática: Neide Shitayama (São Caetano do Sul) } \\
\text { (*O título "Miss Simpática” era escolhido através de votação entre as } \\
\text { candidatas) }\end{array}$ \\
\hline $\begin{array}{l}1975 \\
\text { (Realizado no } \\
\text { teatro da TV Ban- } \\
\text { deirantes) }\end{array}$ & $\begin{array}{l}\text { Miss Colônia: Marli Setsuko Matsuura (Capão Bonito) } \\
\text { Princesas: Maria Tie Katanami (Porto Alegre) } \\
\text { Doroty Izumi (Suzano) } \\
\text { Elvira Mitsuko Kiyomizu (Presidente Prudente) } \\
\text { Michiyo Asô (Porto Alegre) } \\
\text { Miss Simpática: Midori Tangue (São Bernardo do Campo) }\end{array}$ \\
\hline $\begin{array}{l}1976 \\
\text { (Início da realiza- } \\
\text { ção no Anhembi) }\end{array}$ & $\begin{array}{l}\text { Miss Colônia: Lucy Harue Ikematsu (Curitiba) } \\
\text { Princesas: Tomie Sugawara (Rio de Janeiro) } \\
\text { Regina Harumi Iizuka (Saúde) } \\
\text { Sachie Akajiro (Aurora Clube) } \\
\text { Miss Simpática: Marta Michiko Miura (Tucuruvi) }\end{array}$ \\
\hline $\begin{array}{l}1977 \\
\text { (Realizado no } \\
\text { Anhembi) }\end{array}$ & $\begin{array}{l}\text { Miss Colônia: Sueli Yasuko Kakuda (Araçatuba) } \\
\text { Miss Nikkei: Maris Estela Sotoma (Argentina) } \\
\text { Princesas: Dalva Yôko Oikawa (Curitiba) } \\
\text { Sonia Tanizawa (Araçatuba) } \\
\text { Regina Sakakibara (Porto Alegre) } \\
\quad \text { Leiko Kotohashi (Recife) } \\
\text { Miss Simpática: Roseli Miura (Rio de Janeiro) } \\
\text { * Internacionalização do concurso }\end{array}$ \\
\hline
\end{tabular}

* A relação das candidatas nem sempre estará completa devido à falta de dados no anuário ou no jornal. 


\begin{tabular}{|c|c|}
\hline $\begin{array}{l}1978 \\
\text { (Realizado no } \\
\text { Anhembi) }\end{array}$ & $\begin{array}{l}\text { Miss Colônia: Márcia Setsuko Furuno (São Paulo) } \\
\text { Miss Nikkei: Karen Teiko Yano (Havaí) } \\
\text { Princesas: Margarete Nishiyama (Saúde) } \\
\quad \text { Leda Hibari Kanemori (Saúde) } \\
\quad \text { Harumi Nakagawa (Londrina) } \\
\text { Miss Simpática: Márcia Mitsue Kiyomizu (Porto Alegre) } \\
\text { * O nome do concurso internacional se torna "Miss Nikkei Internacional". }\end{array}$ \\
\hline $\begin{array}{l}1979 \\
\text { (Realizado no } \\
\text { Anhembi) }\end{array}$ & $\begin{array}{l}\text { Miss Colônia: Ana Maria Naomi Kurokawa (São Paulo) } \\
\text { Princesa Miss Colônia: } \\
\text { Regina Sonia Kubo (São Paulo) } \\
\text { Akemi Takano (Vila Esperança) } \\
\text { Sachiko Takahashi (Amazonas) } \\
\text { Amélia Suzuki (Marília) } \\
\text { Miss Colônia Simpática: Márcia Hiromi (Paraná) } \\
\text { Miss Nikkei: Débora Miyuki Kodama (Havaí) } \\
\text { Princesa Miss Nikkei: } \\
\text { Mirian Sakaguchi (Peru) } \\
\text { Miss Nikkei Simpática: Patrícia Fujii (Seattle) }\end{array}$ \\
\hline $\begin{array}{l}1980 \\
\text { (Realizado no te- } \\
\text { atro Bandeirantes) }\end{array}$ & $\begin{array}{l}\text { Miss Colônia: Yone Ikeda } \\
\text { Princesa Miss Colônia: Roseli Ueno } \\
\text { Miss Simpática: Masumi Yukawa } \\
\text { Miss Nikkei: Yone Ikematsu } \\
\text { Princesa Miss Nikkei: Harumi de las Casas (Peru) }\end{array}$ \\
\hline $\begin{array}{l}1981 \\
\text { (Realizado no } \\
\text { Anhembi) }\end{array}$ & $\begin{array}{l}\text { Miss Colônia: Suen Nakahara (Rio Grande do Sul) } \\
\text { Princesa Miss Colônia: } \\
\text { Yukie Akiyoshi (São Paulo) } \\
\text { Takako Iizuka (São Paulo) } \\
\text { Miss Simpática: Mayumi Shibata (Mogi das Cruzes) } \\
\text { Miss Nikkei: Posi Mizumoto (Los Angeles) } \\
\text { Princesa Miss Nikkei: Tomoko Mihara (São Francisco) } \\
\quad \text { Susie Arifuji (Peru) } \\
\text { Miss Fotogênica: Karen Kimiko Takaki (Toronto) }\end{array}$ \\
\hline 1982 & Não houve concurso \\
\hline $\begin{array}{l}1983 \\
\text { (Realizado no } \\
\text { Anhembi) }\end{array}$ & $\begin{array}{l}\text { Miss Colônia: Eliana Nomura (Ribeirão Preto) } \\
\text { Miss Nikkei: Eliana Nomura (Ribeirão Preto) } \\
\text { Princesas Miss Nikkei: } \\
\text { Mitsuko Kuroda (Canadá) } \\
\text { Soraia Kawauchi (São Paulo) } \\
\text { Miss Kodak: Eliana Nomura (Ribeirão Preto) }\end{array}$ \\
\hline $\begin{array}{l}1984 \\
\text { (Realizado no } \\
\text { Anhembi) }\end{array}$ & $\begin{array}{l}\text { Miss Colônia: Susi Todo } \\
\text { Miss Nikkei: Akemi Nakanishi (México) } \\
\text { Miss Simpatia: Akemi Nakanishi (México) }\end{array}$ \\
\hline
\end{tabular}




\begin{tabular}{|c|c|}
\hline $\begin{array}{c}1985 \\
\text { (Realizado no } \\
\text { Anhembi) }\end{array}$ & $\begin{array}{l}\text { Miss Colônia: Kiyo Misawa (Curitiba) } \\
\text { Princesa Miss Colônia: Cristiane Kelly Kawaguchi } \\
\quad \text { Lúcia Barbosa Tamaki } \\
\text { Miss Nikkei: Tamlyn Naomi Tomita (Los Angeles) } \\
\text { Princesa Miss Nikkei: } \\
\text { Akemi Kobayashi Sakai (Peru) } \\
\text { Sandy Hitomi (Chicago) }\end{array}$ \\
\hline $\begin{array}{c}1986 \\
\text { (Realizado no } \\
\text { Anhembi) }\end{array}$ & $\begin{array}{l}\text { Miss Colônia: Inês Ogata (São Paulo) } \\
\text { Princesa Miss Colônia: } \\
\text { Jane Iwayama (Santo André) } \\
\text { Cláudia Ogata Miura (Santo Amaro) } \\
\text { Miss Nikkei: Emi Yasumura (Nova Iorque) } \\
\text { Princesa Miss Nikkei: } \\
\text { Delia Inoue (Chicago) } \\
\text { Mayumi Nakasone } \\
\text { Miss Simpatia: Emi Okabe (Califórnia) } \\
\text { * Primeira participação de candidata mestiça de chinês e japonês. }\end{array}$ \\
\hline $\begin{array}{c}1987 \\
\text { (Realizado no } \\
\text { Anhembi) }\end{array}$ & $\begin{array}{l}\text { Miss Colônia: Cláudia Harada (Rio Grande do Sul) } \\
\text { Princesa Miss Colônia: Keila Fukuie } \\
\quad \text { Simone Suguino } \\
\text { Miss Nikkei: Jennifer Kusumoto (Los Angeles) } \\
\text { Princesa Miss Nikkei: Mami Hidaka (Nova Iorque) } \\
\quad \text { Irene Hamamura (Chicago) } \\
\text { Miss Simpatia: Leni Yajima (Havaí) } \\
\text { Miss Fantasia: Neli Nakasone Matsuda (Peru) }\end{array}$ \\
\hline $\begin{array}{c}1988 \\
\text { (Realizado no } \\
\text { Anhembi) }\end{array}$ & $\begin{array}{l}\text { Miss Colônia: Roseli Cristiane Mutai } \\
\text { Princesa Miss Colônia: Suzana Lilian Koga (Londrina) } \\
\qquad \begin{array}{l}\text { Mary Adrian Ishii } \\
\text { (Presidente Prudente) }\end{array} \\
\begin{array}{l}\text { Miss Nikkei: Denise Suemi Katô (Califórnia) } \\
\text { Princesa Miss Nikkei: Yuriko Hirano (Havaí) } \\
\text { Patrícia Barros Moromizato }\end{array}\end{array}$ \\
\hline $\begin{array}{c}1989 \\
\text { (Realizado no } \\
\text { Anhembi) }\end{array}$ & $\begin{array}{l}\text { Miss Colônia: Débora Ôtani (Presidente Prudente) } \\
\text { Princesa Miss Colônia: Pérola Cristina Tamura (São Paulo) } \\
\quad \text { Luciana Andrade Kameyama (Rio de Janeiro) } \\
\text { Miss Nikkei: Débora Mitsunaga (Jundiaí) } \\
\text { Princesa Miss Nikkei: Lisa Yumiko Statch (Chicago) } \\
\text { Joyce Sachiko Hirohata (Califórnia) } \\
\text { Miss Simpatia: Simone Okumoto }\end{array}$ \\
\hline $\begin{array}{c}1990 \\
\text { (Realizado no } \\
\text { Anhembi) }\end{array}$ & $\begin{array}{l}\text { Miss Colônia: Lucrecia Sakamoto } \\
\text { Princesa Miss Colônia: Muriel } \\
\text { Tiane Nakamura } \\
\text { Miss Nikkei: Irina Tsuda (Buenos Aires) } \\
\text { Princesa Miss Nikkei: Marie Miyazaki (Nova Iorque) } \\
\text { Sharon Nakamura (Califórnia) } \\
\text { Garota Kodak: Shisue Mattos Hamada }\end{array}$ \\
\hline
\end{tabular}




\begin{tabular}{|c|c|}
\hline $\begin{array}{c}1991 \\
\text { (Realizado no } \\
\text { Anhembi) }\end{array}$ & $\begin{array}{l}\text { Miss Colônia: Adriana Okada (Pindamonhangaba) } \\
\text { Princesa Miss Colônia: Luciana Possas Gondô (Paraná) } \\
\quad \text { Patrícia Yamaguchi (São Paulo) } \\
\text { Miss Nikkei: Karina Nishino (Brasil) } \\
\text { Princesa Miss Nikkei: Sandra Mizumoto (Los Angeles) } \\
\text { Leika Ninomiya (Seattle) } \\
\text { Miss Kodak: Cíntia Ogama (São Paulo) }\end{array}$ \\
\hline $\begin{array}{c}1992 \\
\text { (Realizado no } \\
\text { Anhembi) }\end{array}$ & 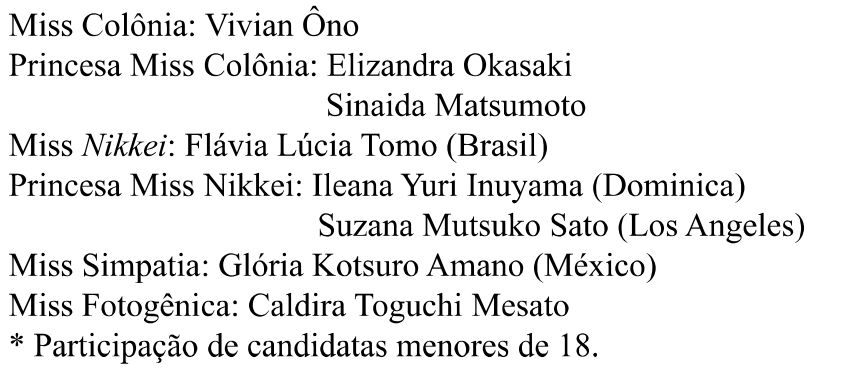 \\
\hline $\begin{array}{c}1993 \\
\text { (Realizado no } \\
\text { Anhembi) }\end{array}$ & $\begin{array}{l}\text { Miss Colônia: Silvana Sanches Nakayama } \\
\text { Princesa Miss Colônia: Karen Tatiane Eiko Noguchi (Paraná) } \\
\text { Liliane Nagumo (Guarulhos) } \\
\text { Miss Nikkei: Daniela Mitsu da Silva (Maringá) } \\
\text { Princesa Miss Nikkei: Pamela Kimura } \\
\quad \text { Daniela Silva (Argentina) } \\
\text { Miss Simpatia: Mirian Hasegawa (Indaiatuba) }\end{array}$ \\
\hline $\begin{array}{c}1994 \\
\text { (Realizado no } \\
\text { Anhembi) }\end{array}$ & $\begin{array}{l}\text { Miss Colônia: Viviane Takabe Egashira (Belém) } \\
\text { Karei Barreira (São Paulo) } \\
\text { Miss Nikkei: Carola Cecília Vieites Kishimoto (Argentina) } \\
\text { Marta Cecília Yuri Takabe (Peru) } \\
\text { Miss Simpática: Carola Cecília Vieites Kishimoto (Argentina) } \\
\text { Miss Kodak: Alessandra Sagawa de Souza (São Paulo) }\end{array}$ \\
\hline
\end{tabular}

